\title{
HYDRODYNAMICS AND HEAT AND MASS TRANSFER IN MUSHROOM- SHAPED HEADS OF THERMOCHEMICAL PLUMES
}

\author{
A. G. Kirdyashkin ${ }^{1}$, A. A. Kirdyashkin ${ }^{1,2}$ \\ ${ }^{1}$ V.S. Sobolev Institute of Geology and Mineralogy, Siberian Branch of RAS, Novosibirsk, Russia \\ ${ }^{2}$ Novosibirsk National Research State University, Novosibirsk, Russia
}

\begin{abstract}
The model of a thermochemical mantle plume is described. The scheme of origination of the plume from the core-mantle boundary is presented. The basic ratios for determining the thermal power and the diameters of thermochemical plumes are given. After eruption of the melt from the plume conduit to the surface, melting occurs along the base of the crustal block above the plume roof, resulting in the formation of a mushroom-shaped head of the plume, which means that a large intrusive body (deep-rooted batholith) is formed. The relative thermal power of such plumes is $1.9<\mathrm{Ka}<10$. Based on the laboratory and theoretical modeling results, we present the thermal and hydrodynamic structure of the thermochemical plume with the mushroom-shaped head. The parameters of some plumes, that are responsible for formations of batholiths in North Asia, are estimated from the geological data, including the age intervals and the extent of magmatism. Relying on the model of the flat horizontal liquid layer, hydrodynamics and heat transfer of the mushroom-shaped plume head are considered. The variations in temperature and flow velocity in the melt of the plume head are assessed. The compositional changes in the melt of the plume head are determined by stages: (1) after settling of refractory minerals; (2) after settling of plagioclase in the melt resulting from the first stage. The tables show the calculation data, including the weight contents of oxides and the normative compositions for the melts at $\mathrm{T}_{\text {melt }}=1410{ }^{\circ} \mathrm{C}$ and $\mathrm{T}_{\text {melt }}=1380{ }^{\circ} \mathrm{C}$. The thickness of the residual melt is estimated for the case of the Khentei plume. Its head's thickness $(l)$ is equal to the plume conduit diameter $(d): l=d=29 \mathrm{~km}$. The proposed model of the plume with the mushroom-shaped head was used to calculate the normative composition of the melt with a chemical composition similar to that of normal granites.
\end{abstract}

Key words: thermochemical plume; thermal power; melt; plume conduit; melt volume; plume head; batholith; normative composition; granite

\section{RESEARCH ARTICLE}

Received: October 27, 2017

Handling Editor: K.Zh. Seminsky

Revised: February 19, 2018

Accepted: February 20, 2018

For citation: Kirdyashkin A.G., Kirdyashkin A.A., 2018. Hydrodynamics and heat and mass transfer in mushroom-shaped heads of thermochemical plumes. Geodynamics \& Tectonophysics 9 (1), 263-286. doi:10.5800/GT-2018-9-1-0348.

Для цитирования: Кирдяшкин А.Г., Кирдяшкин А.А. Гидродинамика и тепломассообмен в грибообразной голове термохимического плюма // Геодинамика и тектонофизика. 2018. Т. 9. № 1. С. 263-286. doi:10.5800/GT-2018-9-1-0348. 


\title{
ГИДРОДИНАМИКА И ТЕПЛОМАССООБМЕН В ГРИБООБРАЗНОЙ ГОЛОВЕ ТЕРМОХИМИЧЕСКОГО ПЛЮМА
}

\author{
А. Г. Кирдяшкин ${ }^{1}$, А. А. Кирдяшкин ${ }^{1,2}$ \\ ${ }^{1}$ Институт геологии и минералогии им. В.С. Соболева СО РАН, Новосибирск, Россия
${ }^{2}$ Новосибирский национальный исследовательский государственный университет,
Новосибирск, Россия
}

Аннотация: Описана модель мантийного термохимического плюма, и представлена схема его зарождения на границе ядро-мантия. Приведены основные соотношения для определения тепловой мощности термохимического плюма и диаметра его канала. Плюмы с грибообразной головой имеют относительную тепловую мощность $1.9<$ Ка<10. После прорыва расплава из канала плюма на поверхность происходит плавление вдоль подошвы массива коры над кровлей плюма и образуется грибообразная голова плюма, т.е. формируется крупное интрузивное тело (корневой батолит). На основе данных лабораторного и теоретического моделирования представлена тепловая и гидродинамическая структура термохимического плюма с грибообразной головой. Определены основные параметры некоторых плюмов, ответственных за образование батолитов Северной Азии. Гидродинамика и теплообмен в грибообразной голове плюма рассмотрены на основе модели плоского горизонтального слоя жидкости. Оценены величины изменения температуры и скорости течения в расплаве головы плюма. Расчеты состава расплава в грибообразной голове плюма проведены в два этапа: 1) после осаждения тугоплавких минералов на подошву головы плюма; 2) после осаждения плагиоклаза в расплаве, образовавшемся после первого этапа и содержащем 61.5 \% плагиоклазового компонента. Результаты расчетов приведены в виде таблиц, представляющих процентное весовое содержание оксидов, а также нормативный минералогический состав расплава при температуре $T_{\mathrm{p}}=1410{ }^{\circ} \mathrm{C}$ и $T_{\mathrm{p}}=1380{ }^{\circ} \mathrm{C}$. Расчеты толщины слоя остаточного расплава проведены для Хэнтэйского плюма, у которого толщина головы $l=d=29$ км $(d-$ диаметр канала плюма). На основе предложенной модели плюма с грибообразной головой в результате расчетов может быть получен нормативный состав расплава, близкий к составу нормальных гранитов.

Ключевые слова: термохимический плюм; тепловая мощность; расплав; канал плюма; голова плюма; объем расплава; батолит; нормативный состав; гранит

\section{1. ВВЕДЕНИЕ}

Процессы тепло- и массообмена на границе ядро - мантия во многом определяют работу термохимической машины Земли. На этой границе формируются мантийные термохимические плюмы. Тектоника горячих полей, непосредственно связанных с мантийными плюмами, в значительной мере регулирует глобальную геодинамику Земли [Dobretsov et al., 2001, 2005; Maruyama, 1994; Zonenshain et al., 1991]. Предложена модель термохимического плюма, формирующегося на границе ядро - мантия при наличии теплового потока из внешнего ядра и локальном поступлении химической добавки, понижающей температуру плавления мантии [Kirdyashkin et al., 2004]. В работах [Dobretsov et al., 2005, 2008] был проанализирован тепло- и массоперенос термохимического плюма и оценены его основные параметры. Данные лабораторного и теоретического моделирования подъема (выплавления) канала плюма, его конфигурации, структуры свободно-конвективных течений в нем, а также излияния расплава из канала представлены в статьях [Dobretsov et al., 2008; Gladkov et al., 2012]. Построена диаграмма геодинамических режимов мантийных плюмов [Kirdyashkin et al., 2016].

Ранее и в настоящее время получили развитие химические и петрологические модели образования гранитов. Многочисленные эксперименты направлены на изучение плавления и кристаллизации гранитов для ряда синтетических и природных систем, ключевая роль отводится изучению влияния воды на понижение температуры плавления [Tuttle, Bowen, 1958; Luth et al., 1964; Maaløe, Wyllie, 1975; Johannes, 1984; Whitney, 1988; Brown, 2013; и дp.]. Однако создание моделей образования гранитов требует комплексного подхода: химические и петрологические модели должны быть поддержаны необходимым количеством тепловой энергии при соответствующих $P$-T-параметрах. Другими словами, в модельных построениях необходимо определить источник тепла и его параметры (размеры, тепловая мощность). При этом должны быть выполнены и законы сохранения импуль- 
са и массы. Необходимо также определить величину сил, отвечающих за создание крупных интрузивных тел (гранитных батолитов). Таким образом, в исследованиях процессов образования гранитов химические и петрологические модели должны быть поддержаны моделями тепловой и гидродинамической структуры термохимического плюма. В этом случае возможно обоснование справедливости идей и гипотез, положенных в основу той или иной петрологической модели.

В настоящей статье на основе геологических данных определены тепловые мощности мантийных термохимических плюмов, ответственных за образование крупных интрузивных тел, в том числе батолитов. Для этих тепловых мощностей рассмотрены гидродинамика и теплообмен в каналах плюмов. Оценены размеры грибообразной головы плюма, представляющей собой расплав корового слоя, над которым расположен твердый массив толщиной $\delta$. Определены перепад температуры и скорость горизонтальных течений в расплаве головы плюма. На основе данных о тепловой и гидродинамической структуре головы плюма и среднего химического состава земной коры представлено возможное изменение состава расплава в голове плюма последовательно для двух этапов: 1) после осаждения твердой фазы (тугоплавких минералов) на подошву головы плюма; 2) после осаждения плагиоклаза в расплаве, образовавшемся после первого этапа. Остаточный расплав, образовавшийся в результате кристаллизационной дифференциации, по составу оказался близким к нормальным гранитам. В течение времени существования плюма этот расплав под действием сверхлитостатического давления у кровли плюма внедряется в массив над ней. Исследования выполнены для случаев, когда температура плавления корового слоя составляет 1410 и $1380{ }^{\circ} \mathrm{C}$. При этом температура плавления «сухого» гранита достигает $1215-1260^{\circ} \mathrm{C}$ [Larsen, 1929].

\section{2. МОДЕЛЬ МАНТИЙНОГО ТЕРМОХИМИЧЕСКОГО ПЛЮМА}

Анализ свободно-конвективного теплообмена во внешнем ядре на основе модели горизонтального слоя вязкой жидкости, подогреваемого снизу и охлаждаемого сверху, показал, что при физических свойствах внешнего ядра и тепловом потоке на границе ядро - мантия $q_{1}=10 q=0.6 \mathrm{BT} / \mathrm{M}^{2}(q-$ средний тепловой поток на земной поверхности) сверхадиабатический перепад температуры между кровлей и подошвой внешнего ядра составляет $\sim 0.3{ }^{\circ} \mathrm{C}$ [Dobretsov et al., 2001]. Длительное существование высоких сверхадиабатических перепадов температуры на границе ядро - мантия невоз- можно из-за интенсивной свободной конвекции в жидком внешнем ядре, поэтому невозможно возникновение высокотемпературных тепловых источников на границе ядро - мантия, вследствие которых могли бы зарождаться тепловые плюмы. Однако на границе ядро - мантия из-за сложных физико-химических процессов взаимодействия внешнего ядра и нижней мантии могут присутствовать значительные композиционные неоднородности (например [Brandon, Walker, 2005]). Последние могут быть причиной понижения температуры плавления вещества мантии.

Согласно модели [Kirdyashkin et al., 2004; Dobretsov et al., 2008], термохимический плюм формируется на границе ядро - мантия там, где локализована химическая добавка, понижающая темпера-

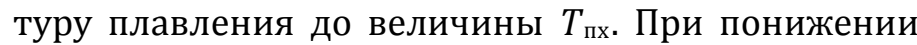
температуры плавления мантийного вещества ниже температуры границы ядро - мантия $T_{1}$ происходит плавление в мантии и формирование плюма. Тепловым источником является внешнее жидкое ядро, имеющее в области локального поступления химической добавки бо́льшую температуру, чем температура плавления мантии.

Источником химической добавки могут быть реакции железосодержащих минералов нижней мантии (перовскита, магнезиовюстита) с водородом и/или метаном, выделяющимися на границе ядро - мантия [Kirdyashkin et al., 2004]. Температуру плавления мантии при наличии химической добавки можно определить таким образом: $T_{\text {пх }}=$ $=T_{\text {пс }}-k c_{2}$, где $T_{\text {пс }}-$ температура плавления «сухой» окружающей мантии (без добавки), коэффициент $k$ $\left({ }^{\circ} \mathrm{C} / \%\right)$ характеризует величину понижения температуры плавления при увеличении концентрации добавки на 1 мас. \%, $c_{2}$ - концентрация добавки на границе канала плюма. Тогда можно записать: $T_{1}-T_{\text {пх }}=k c_{2}-\left(T_{\text {пс }}-T_{1}\right)$. Плавление мантийного вещества вблизи границы ядро - мантия и, соответственно, формирование термохимического плюма возможно, когда разность $T_{\text {пс }}-T_{1}>0$, т.е. когда выполняется условие $k c_{2}>\left(T_{\text {пс }}-T_{1}\right)$ и, следовательно, $c_{2}>T_{\text {пс }}-T_{1} / k$. Эти условия выполняются при $c_{2}=$ $=2-3 \%$ и $k=30-40{ }^{\circ} \mathrm{C} / \%$ [Kirdyashkin et al., 2004]. Легкие химические добавки (предположительно водород, метан, вода, $\mathrm{CO}_{2}$ ), находящиеся во внешнем жидком ядре, имеющие плотность, меньшую, чем расплав ядра, будут подниматься к границе ядро - мантия и располагаться вдоль границы ядро - мантия (рис. 1).

\section{3. ЗАРОЖДЕНИЕ МАНТИЙНОГО ПЛЮМА}

Зарождение и формирование канала плюма могут происходить в области нисходящего ман- 


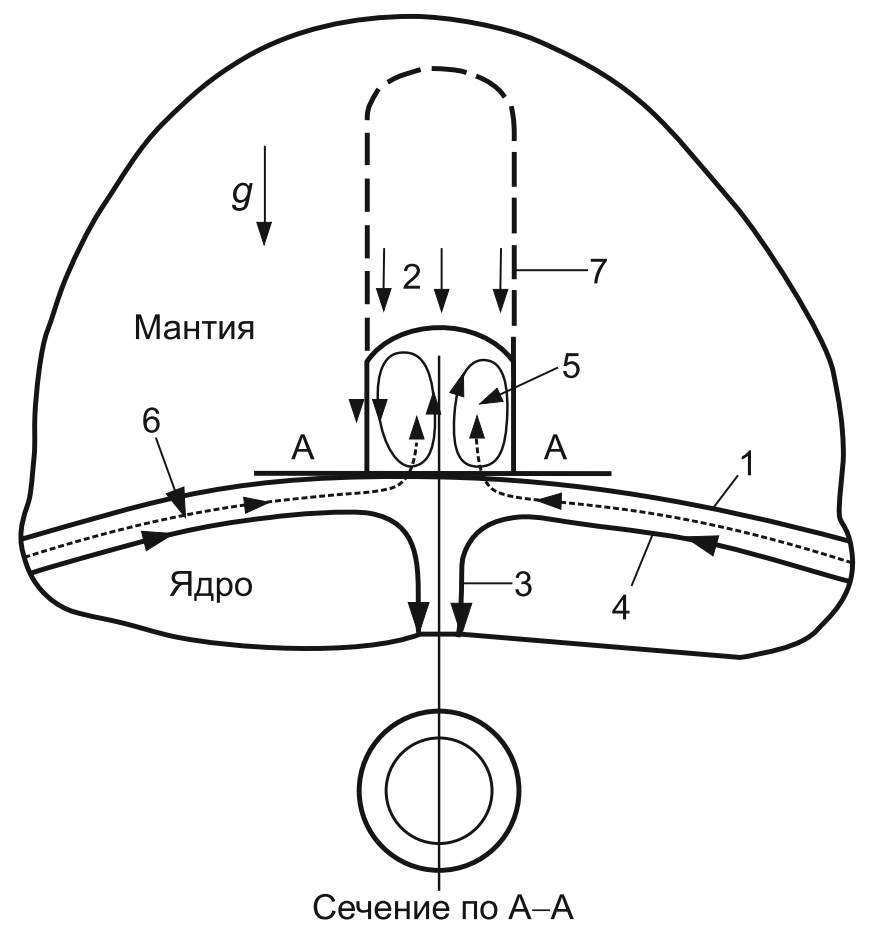

Рис. 1. Схема зарождения термохимического плюма на границе ядро - мантия.

1 - граница ядро - мантия, 2 - нисходящее нижнемантийное течение, 3 - нисходящее течение во внешнем ядре, 4 - горизонтальные течения во внешнем ядре, 5 - очаг плавления, 6 - поток химической добавки в очаг плавления, 7 - канал поднимающегося плюма.

Fig. 1. Scheme of thermochemical plume formation at the core - mantle boundary.

1 - core - mantle boundary, 2 - descending flow in the lower mantle, 3 - descending flow in the outer core, 4 - horizontal flows in the outer core, 5 - melting region, 6 - inflow of a chemical dope into the melting region, 7 - conduit of the ascending plume.

тийного свободно-конвективного течения следующим образом (рис. 1). На границе ядро - мантия 1 в области нисходящего мантийного потока 2 возникает понижение температуры, вследствие чего образуется свободно-конвективное нисходящее течение 3 в ядре. Во внешнем ядре вдоль границы ядро - мантия образуются горизонтальные течения 4 вследствие горизонтального градиента температуры вдоль границы ядро - мантия, который является результатом понижения температуры в области нисходящих течений в мантии и ядре [Dobretsov et al., 2001; Dobretsov, Kirdyashkin, 2000], как показано на рис. 1. В области сходящихся горизонтальных течений 4 под действием силы Кориолиса образуется вихревое течение, концентрирующее легкие химические добавки [Dobretsov, Kirdyashkin, 2000]. Происходит взаимодействие химических добавок с мантийным веществом. В области вихревого течения понижается температура плавления мантии, вследствие чего мантийное ве- щество начинает плавиться. В зарождающийся очаг мантийного расплава 5 втекают снизу из внешнего ядра легкие компоненты химической добавки 6. Таким образом, вначале вследствие возникшего вихревого течения происходит накопление химической добавки, понижающей температуру плавления мантийного вещества, а затем под действием архимедовой силы легкие компоненты химической добавки втекают в образовавшийся очаг плавления 5 (рис. 1). Химическая добавка постоянно подтекает от границы ядро - мантия в сформировавшийся очаг расплава (канал плюма), и происходит выплавление мантийного вещества на кровле плюма вследствие поступления тепла от ядра в области подошвы плюма, т.е. происходит выплавление (подъем) канала плюма 7. Подошва плюма расположена на границе раздела расплава мантийного вещества и внешнего жидкого ядра.

На дальнейший процесс плавления мантийное нисходящее течение уже не влияет, решающее влияние на плавление оказывает высокий локальный тепловой поток в канал плюма от подошвы и интенсивный подвод тепла из ядра в область подошвы плюма. Скорость нисходящего мантийного течения на несколько порядков меньше, чем скорость выплавления (подъема) плюма.

Относительно возможности существования в мантии плюмов в виде восходящих свободноконвективных течений (термиков) можно заметить следующее. Экспериментальные исследования структуры ячеистых течений в горизонтальном слое вязкой жидкости, нагреваемом снизу и охлаждаемом сверху, показали, что граница возникновения развитой турбулентной свободной конвекции при числах $\operatorname{Pr}>50$ не зависит от числа Прандтля $\operatorname{Pr}=v / a$ и значение граничного числа Рэлея $\mathrm{Ra}=\beta g \Delta T l^{3} / a v=10^{6}$, где $v$ - кинематическая вязкость жидкости, $a$ - коэффициент температуропроводности, $\beta$ - коэффициент теплового объемного расширения, $g$ - ускорение силы тяжести, $\Delta T-$ перепад температуры в слое [Dobretsov et al., 2001]. Для нижней мантии, моделью которой является горизонтальный слой вязкой жидкости, подогреваемый снизу и охлаждаемый сверху, Ra=106-107.5, и, следовательно, характерным является турбулентный режим свободно-конвективного течения [Dobretsov et al., 2001]. Понятие «термик» возникло при изучении свободно-конвективного течения над локальным источником тепла в большом объеме жидкости. На границе ядро - мантия возникновение локального теплового источника невозможно, о чем было сказано в предыдущем разделе. Экспериментальные исследования зарождения и развития свободно-конвективных течений в горизонтальном слое жидкости, нагреваемом снизу и охлаждаемом сверху, при $\mathrm{Ra}<10^{6}$ и в интервале 
$\mathrm{Ra}=10^{6}-10^{7.5}$ не обнаруживают возникновения термиков. В горизонтальном слое подъемные и опускные течения условно индивидуальны только в момент возникновения конвекции. При развитой конвекции в интервале $\mathrm{Ra}=10^{6}-10^{7}$ в горизонтальном слое жидкости не наблюдаются отдельные восходящие и нисходящие потоки (термики), но существуют подъемные, опускные и горизонтальные течения, имеющие соизмеримые по величине скорости, т.е. существуют нестационарные ячеистые течения [Dobretsov et al., 2001].

\section{4. ОПРЕДЕЛЕНИЕ ТЕПЛОВОЙ МОЩНОСТИ И ДИАМЕТРА ТЕРМОХИМИЧЕСКОГО ПЛЮМА}

Представим выражения для оценки тепловой мощности термохимического плюма, используя способ, предложенный в статье [Dobretsov et al., 2005]. Тепловую мощность рассматриваемого плюма можно рассчитать по массовому расходу поднявшейся и излившейся магмы выше нижнего топографического уровня. Массу поднявшейся и излившейся магмы можно оценить по остаточному рельефу следа плюма над нижним топографическим уровнем в его окрестности. Эту массу П.Р. Фогт определяет как «cross-chain mass» [Vogt, 1979]. Подъем и излияние магмы длительно действующего плюма происходят главным образом вследствие теплового расширения мантийного вещества, нагретого источником плюма: вещество окружающей мантии, нагретое источником, при расширении выдавливает расплав из канала плюма. В модели термохимического плюма [Kirdyashkin et al., 2004] тепло- и массообмен в канале действующего плюма происходит в условиях свободной конвекции. В этом случае в каждом поперечном сечении канала расход расплава, согласно закону сохранения вещества, равен нулю, за исключением той малой части, которая выдавлена из канала вследствие расширения мантии при нагреве в окрестности канала.

Зная время, в течение которого сформировалось поднятие над нижним топографическим уровнем, можно определить объем магмы, излившейся на поверхность в единицу времени, или, другими словами, объемный расход магмы $\Delta V\left(\mathrm{~m}^{3} / \mathrm{c}\right)$, используя который можно найти массовый расход:

$$
\Delta G=\rho \Delta V
$$

где $\rho$ - плотность магматического расплава.

Массовый расход магмы можно определить также из соотношения:

$$
\Delta G=G \beta \Delta T,
$$

где $G$ - масса мантийного вещества, нагреваемого источником плюма в единицу времени, $\Delta T$ - среднее увеличение температуры нагретого вещества массой $G$ относительно температуры окружающей мантии, $\beta$ - коэффициент теплового объемного расширения мантийного вещества. Из соотношения (2) находим массу мантийного вещества $G$, нагреваемого источником плюма в единицу времени:

$$
G=\Delta G / \beta \Delta T
$$

Тепловая мощность источника плюма определяется из соотношения:

$$
N=G C \Delta T+B \Delta G
$$

где $C$ - теплоемкость мантийного вещества, $B$ теплота его плавления. В выражении (4) первое слагаемое учитывает тепло, затраченное на нагрев мантийного вещества, второе - тепло, затраченное на плавление магмы, излившейся из канала плюма. Подставляя соотношение (3) в равенство (4), получаем:

$$
N=\Delta G[(C / \beta)+B]
$$

В соотношении (5) учитывается все тепло источника плюма: тепло, отведенное от канала плюма в нижнюю и верхнюю мантию, и тепло, затраченное на плавление. Для определения мощности плюма используются геологические данные о массе излившейся магмы и физические свойства мантийного вещества $(C, \beta, B)$. Следует отметить, что величина $B$ меньше величины $C / \beta$ на порядок, и ею можно пренебречь. Тогда равенство (5) записывается в виде:

$$
N=\Delta G C / \beta
$$

Таким образом, тепловую мощность, передающуюся от подошвы плюма в его канал, мы вычисляем по массовому расходу магмы, изливающейся на дневную поверхность, который определяется из геологических данных. Зная тепловую мощность плюма $N$, определяемую из соотношения (6) по массовому расходу расплава, можно найти диаметр канала плюма $d$ из соотношения [Dobretsov et al., 2005]:

$$
d=\left[N(a v)^{1 / 3} / 0.045 \pi \lambda \Delta T_{\mathrm{s}}{ }^{4 / 3}(\beta g)^{1 / 3}\right]^{1 / 2},
$$

где $a$ - температуропроводность расплава в канале плюма, $v$ - кинематическая вязкость расплава, в общем случае зависящая от доли расплава $\varphi$, $\lambda$ - теплопроводность расплава, $\Delta T_{\mathrm{s}}=\left(T_{1}-T_{\text {пх }}\right) / 1.57-$ 
перепад температуры в пограничном слое вблизи подошвы.

\section{5. СТРУКТУРА КАНАЛА ТЕРМОХИМИЧЕСКОГО ПЛЮМА В ПЕРИОД ПОДЪЕМА НА ПОВЕРХНОСТЬ}

Результаты исследований структуры термохимического плюма представлены в работе [Gladkov et al., 2012]. Мантийный плюм, зарождающийся на границе ядро - мантия, в период своего подъема (выплавления канала) представляет собой систему, состоящую из подошвы плюма, расположенной на границе ядро - мантия, от которой к расплаву канала передаются тепло и химическая добавка, понижающая температуру плавления мантийного вещества, и канала плюма, по которому в условиях свободной конвекции тепло и химическая добавка транспортируются к кровле плюма. Тепло, переданное от подошвы плюма, расходуется на нагрев окружающего мантийного вещества и его плавление у кровли плюма. Согласно экспериментам [Gladkov et al., 2012], поперечные сечения канала плюма представляют собой эллипсы. В соответствии со снимками каналов плюмов, отношение больших осей эллипсов к малым составляет величину, меньшую, чем 1.2. В дальнейших оценках будем принимать средний диаметр канала плюма.

Под тектонически стабильными континентальными регионами мантийный тепловой поток достаточно низкий (например [Dobretsov et al., 2001; Jaupart, Mareschal, 2007, 2014]). Низкие тепловые потоки указывают на низкую интенсивность свободно-конвективных течений в мантии в таких регионах. Таким образом, для плюма, существующего под кратоном, можно не учитывать влияние мантийных свободно-конвективных течений [Dobretsov et al., 2005]. В статье [Gladkov et al., 2012] представлен анализ соотношения температуры плавления мантии, рассчитанной в работе [Walzer et al., 2004], и температуры расплава в канале плюма в условиях кондуктивного теплоотвода от канала в окружающую мантию. Согласно выводам [Gladkov et al., 2012], мантийный плюм зарождается на границе ядро - мантия и поднимается от нее до уровня $x_{\mathrm{Tx}}=148-185$ км как термохимический. При $x>X_{\mathrm{Tx}}$ определяющими процессами при выплавлении канала плюма являются тепловые процессы, а не диффузионные, как это наблюдается в период зарождения плюма и его подъема до уровня $x=x_{\mathrm{Tx}}$.

Как показывает лабораторное моделирование [Gladkov et al., 2012], в вертикальном сечении канал плюма представляет собой систему конвективных ячеек (рис. 2). В областях сужения на границах ячеек восходящий конвективный поток переходит на противоположную сторону канала. Пограничный

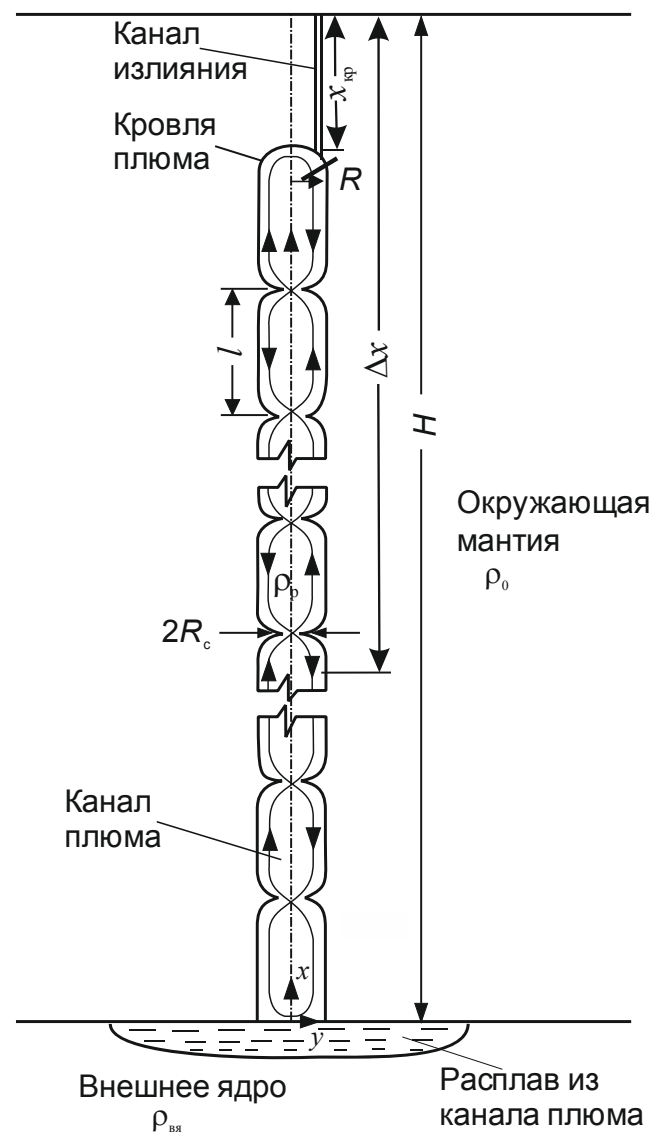

Рис. 2. Схема канала плюма радиусом $R$, поднявшегося от границы ядро - мантия до уровня, на котором фор-

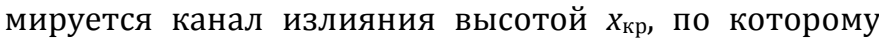
магматический расплав прорывается на поверхность. Показаны свободно-конвективные течения в расплаве канала плюма. $\Delta x-$ глубина, соответствующая объему расплава, излившегося на поверхность, $l$ - высота конвективной ячейки в канале. Радиус сужений, создающихся на границах конвективных ячеек, $R_{c}=R / 2$.

Fig. 2. Diagram of the plume conduit with radius $R$, which ascended from the core - mantle boundary to the level at

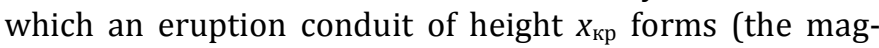
matic melt erupts through this conduit to the surface). Free-convection flows in the melt of the plume conduit are shown. $\Delta x$ is the depth corresponding to the melt volume erupted to the surface; $l$ is the height of a convection cell in the conduit. The radius of narrowed zones appearing at the boundaries of convection cells is $R_{\mathrm{c}}=R / 2$.

слой нисходящего конвективного течения расположен по образующей поверхности канала. Граница канала изменяется во времени. Вдоль области восходящего потока происходит плавление, вдоль нисходящего потока - кристаллизация на границе и в областях сужения канала. В лабораторном моделировании обнаруживается перемещение сужений вверх по каналу вида «бегущей волны», между границей канала и окружающим массивом происходит нестационарный кондуктивный теплообмен. 
Средний диаметр канала плюма $d=2 R(R-$ средний радиус канала) соизмерим с диаметром его подошвы. Средний диаметр сужения канала $d_{\mathrm{c}}=2 R_{\mathrm{c}}=0.5 d$, где $R_{\mathrm{c}}$ - средний радиус сужения [Kirdyashkin A.A., Kirdyashkin A.G., 2016].

В качестве масштаба тепловой мощности принята мощность, при которой тепло от канала плюма передается в окружающую мантию в условиях стационарной теплопроводности. В этом случае тепловая мощность, переданная каналом плюма окружающей мантии, определяется из соотношения [Gladkov et al., 2012]:

$$
N_{1}=0.5 \pi \lambda \Delta T H,
$$

где $\lambda$ - средняя по высоте канала плюма теплопроводность мантии, $\Delta T=T_{\text {пл }}-T_{0}-$ средний по высоте канала плюма перепад температуры между границей канала плюма и окружающей мантией, $H$ - высота выплавленного канала плюма.

Будем рассматривать относительную тепловую мощность плюма:

$$
\mathrm{Ka}=N / N_{1},
$$

где $N$ - тепловая мощность источника плюма. Критерий Ка (относительная тепловая мощность) показывает, во сколько раз тепловая мощность, подводящаяся на подошве плюма, больше тепловой мощности, отдаваемой в окружающую мантию в режиме стационарной теплопроводности. Для стационарного кондуктивного теплообмена между каналом и окружающим массивом Ка=1 $\left(N=N_{1}\right)$. Экспериментальные исследования конфигурации плюма, возникающего при плавлении массива парафина над локальным источником тепла, показали, что величина критерия Ка для плюма, выходящего на поверхность массива высотой $H$, равна $\mathrm{Ka}_{\text {пр1 }}=N_{\text {пр} 1} / N_{1}=1.12-1.17$, где $N_{\text {пр1 }}$ - тепловая мощность источника плюма, при которой плюм еще достигает поверхности (предельная тепловая мощность) [Gladkov et al., 2012]. Величина критерия Ка пр1 для плюмов, достигающих поверхности, больше единицы, потому что возникает неустойчивость границы канала плюма и интенсивность кондуктивного теплообмена при нестационарных условиях увеличивается на 12-17 \% по сравнению со стационарным режимом теплопроводности [Gladkov et al., 2012].

\section{6. ГИДРОДИНАМИКА И ТЕПЛООБМЕН В ГРИБООБРАЗНОЙ ГОЛОВЕ ПЛЮМА}

На рис. 3 на основе данных лабораторного моделирования [Gladkov et al., 2012; Kirdyashkin et al.,
2017] построена схема термохимического плюма с грибообразной головой, ответственного за образование крупного интрузивного тела (батолита). Грибообразная голова плюма возникает после прорыва расплава из канала плюма на поверхность при значениях относительной тепловой мощности $1.9<\mathrm{Ka}<10$ [Kirdyashkin et al., 2017]. После прорыва плюма на поверхность тепловая мощность, передаваемая к кровле плюма, равна

$$
\Delta N=N-N_{\text {пр } 1},
$$

где $N=\mathrm{Ka}_{1}$ - тепловая мощность, передающаяся от подошвы плюма в его канал, $N_{\text {пр1 }}=\mathrm{Ka}_{\text {пр } 1} N_{1}$ - тепловая мощность, передаваемая каналом плюма окружающей мантии в режиме нестационарной теплопроводности, $\mathrm{Ka}_{\text {пр1 }}=1.15$ [Gladkov et al., 2012].

Величина $N_{\text {пр1 }}=1.6 \cdot 10^{10}$ Вт [Kirdyashkin et al., 2016]. Тепловая мощность, отводимая от кровли плюма в атмосферу через массив толщиной $\delta$ над кровлей плюма, меньше по сравнению с тепловой мощностью $\Delta N$, и поэтому происходит плавление вдоль подошвы массива над кровлей плюма и образуется грибообразная голова плюма, т.е. происходит процесс формирования корневого батолита (рис. 3). В процессе роста грибообразной головы плюма в ее расплаве развиваются свободно-конвективные течения. Их развитие происходит под действием горизонтального градиента температуры в голове плюма.

Рассмотрим случай, когда грибообразная голова плюма достигает своего наибольшего диаметра $d_{\text {г,max }}$ в момент времени $t=t_{\text {пл }}$ (рис. 3). Это происходит, когда тепловая мощность $\Delta N=N-N_{\text {пр1 }}$ становится равной тепловой мощности, передаваемой к поверхности через массив толщиной $\delta$ над кровлей плюма.

Удельный тепловой поток через массив над кровлей плюма, имеющий толщину $\delta$,

$$
q_{\mathrm{r}}=\lambda_{\delta}\left(\Delta T_{\delta} / \delta\right)
$$

где $\lambda_{\delta}=3.5 \mathrm{BT} /{ }^{\circ}{ }^{\circ} \mathrm{C}-$ коэффициент теплопроводности массива над кровлей плюма, $\Delta T_{\delta}=T_{\mathrm{r}}-T_{\text {дп }}=$ $=1200{ }^{\circ} \mathrm{C}$, где $T_{\mathrm{r}}-$ температура кровли плюма, $T_{\text {дп }}-$ температура дневной поверхности. Через массив толщиной $\delta$ передается количество тепла, соответствующее тепловой мощности $\Delta N$, равной

$$
\Delta N=\left(\mathrm{Ka}-\mathrm{Ka}_{\text {пр1 }}\right) N_{1} .
$$

Площадь поверхности массива над грибообразной головой плюма $S=\pi d_{\mathrm{r}}{ }^{2} / 4=\Delta N / q_{\mathrm{r}}$. Учитывая это равенство и используя соотношения (11), (12), получаем:

$$
d_{\Gamma}=\left[4 N_{1} \delta\left(\mathrm{Ka}-\mathrm{Ka}_{\text {пр } 1}\right) / \pi \lambda_{\delta} \Delta T_{\delta}\right]^{1 / 2},
$$




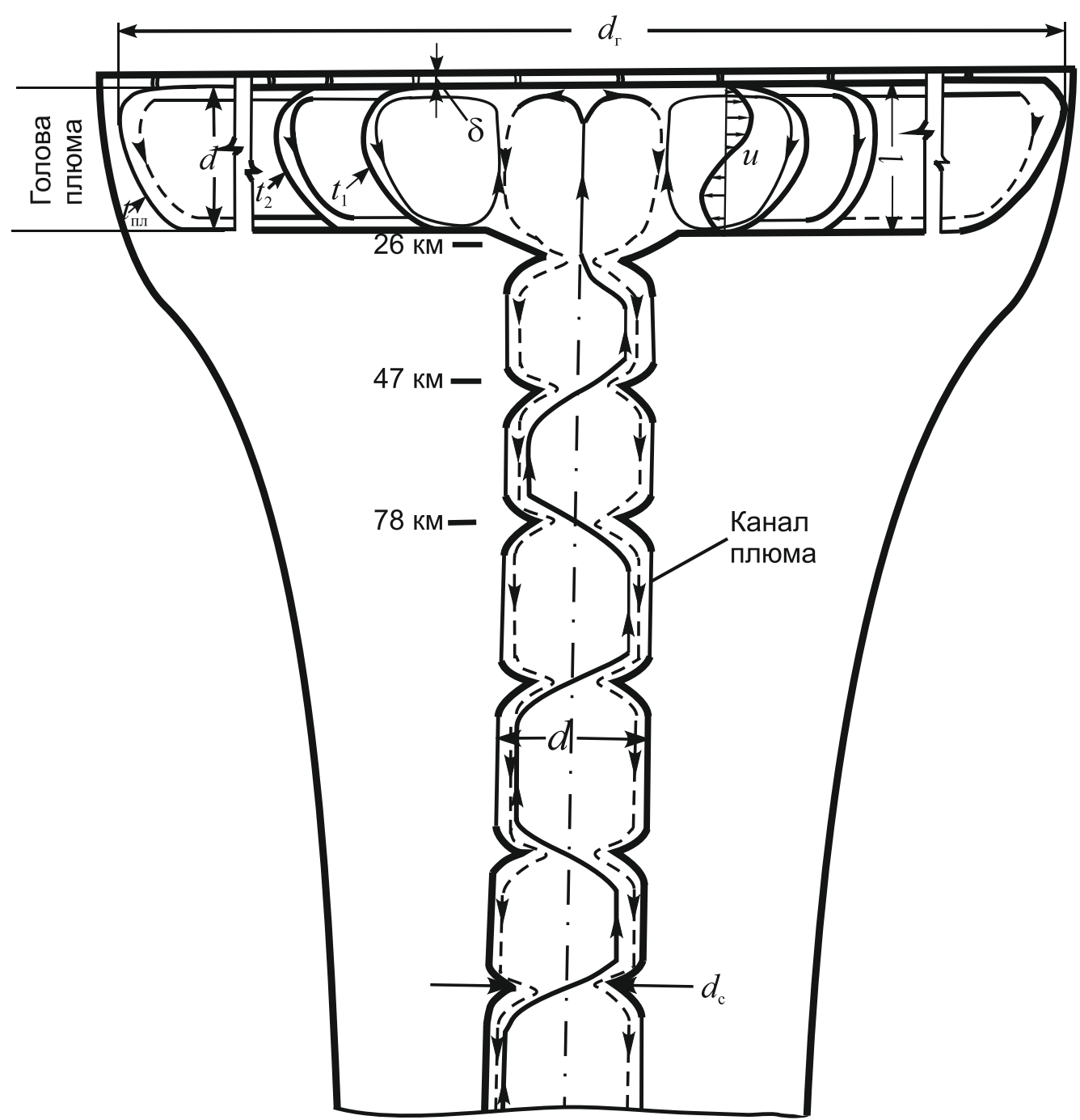

Рис. 3. Схема свободно-конвективных течений в расплаве канала и в расплаве грибообразной головы плюма в процессе ее образования за время $t\left(t_{1}<t<t_{\text {пл}}\right)$. Средняя толщина грибообразной головы плюма $l$ равна (в первом приближении) диаметру его канала $d, \delta$ - толщина массива над головой плюма. Показан профиль горизонтальной скорости течения в расплаве головы плюма $u$.

Fig. 3. Scheme of free-convection flows in the melt of the plume conduit and in the mushroom-shaped plume head during its formation in time $t\left(t_{1}<t<t_{\text {melting }}\right)$. As the first approximation, the average thickness of the plume head $l$ is equal to the plume conduit diameter $d ; \delta$ is the thickness of the block above the plume head. The horizontal velocity profile of the melt flow in the plume head is shown.

$$
\delta=S \lambda_{\delta} \Delta T_{\delta} / N_{1}\left(\mathrm{Ka}-\mathrm{Ka}_{\text {пр} 1}\right) .
$$

Таким образом, толщина корового слоя над головой плюма $\delta$ может быть определена из соотношения (14) с использованием геологических данных о размерах магматических ареалов плюмов, представленных, например, в работе [Kuzmin et al., 2010].

Давление в расплаве под кровлей плюма, поднимающегося (выплавляющегося) в мантии, превышает литостатическое давление пород над кровлей плюма на величину $\Delta P$. Согласно [Dobretsov et al., 2008], при постоянном значении диаметра канала (и кровли) плюма $\Delta P=\rho_{0} \beta g\left(H-X_{\text {кр }}\right)\left(T_{\mathrm{p}}-T_{0}\right)$, где $\rho_{0}$ - плотность окружающей мантии, $x_{\text {кр }}$ - высота канала излияния. С учетом сужений канала плюма сверхлитостатическое давление на его кровле

$$
\Delta P=\rho_{0} \beta g\left(H-X_{\text {кр }}\right)\left(T_{\mathrm{p}}-T_{0}\right)\left(R_{\mathrm{c}} / R\right)^{2} .
$$

Для значений параметров $\rho_{0}=4500$ кг $/ \mathrm{m}^{3}, \beta=$ $=(1-3) \cdot 10^{-5}{ }^{\circ} \mathrm{C}^{-1}, g=9.8 \mathrm{M} / \mathrm{c}^{2}, H=2.88 \cdot 10^{6} \mathrm{M}, X_{\text {кр }}=12 \cdot 10^{3} \mathrm{M}$, $T_{\mathrm{p}}-T_{0}=440^{\circ} \mathrm{C} \quad$ и $\quad\left(R_{\mathrm{c}} / R\right)^{2}=0.25$ получаем $\Delta P=(1.4-$ $-4.2) \cdot 10^{8} \mathrm{H} / \mathrm{m}^{2}\left(10^{8} \mathrm{H} / \mathrm{m}^{2}=1\right.$ кбар). Сила давления на кровлю поднимающегося плюма диаметром $d$, равная $\Delta P\left(\pi d^{2} / 4\right)$, вызывает движение в массиве коры, находящемся над кровлей плюма.

Сверхлитостатическое давление в расплаве у кровли грибообразной головы плюма диаметром 
$d_{\Gamma}$, обусловленное архимедовой силой расплава в канале плюма, $\Delta P_{\kappa}=\Delta P\left(d / d_{\Gamma}\right)^{2}$. Давление в расплаве под кровлей головы плюма толщиной $l$, обусловленное разностью плотностей расплава и окружающей коры, больше литостатического давления пород над ней на величину

$$
\Delta P_{\text {гп }}=\rho \beta g \Delta T_{\text {гा }} l,
$$

где $\rho$ - плотность расплава, $\Delta T_{\text {гп }}=T_{\mathrm{p}, \text { гп }}-T_{0}, T_{\mathrm{p}, \text { гп }}-$ температура расплава головы плюма, $T_{0}$ - температура окружающего корового массива. Из соотношения (16) для $\beta=(5-7) \cdot 10^{-5}{ }^{\circ} \mathrm{C}^{-1}, \rho=3200 \mathrm{\kappa г} / \mathrm{M}^{3}, g=9.8 \mathrm{м} / \mathrm{c}^{2}$, $\Delta T_{\mathrm{rn}}=1200^{\circ} \mathrm{C}, \quad l \approx d=3 \cdot 10^{4} \quad$ м получаем $\quad \Delta P_{\text {гп }}=565-$ 790 бар. Из соотношения (16) следует, что величиной, определяющей сверхлитостатическое давление у кровли головы плюма $\Delta P_{\text {гп }}$, является толщина головы плюма $l$. Принимая на основании оценок размеров плюмов с грибообразной головой (см. ниже) $d=3 \cdot 10^{4}$ м и $d_{\mathrm{r}}=3 \cdot 10^{5} \mathrm{M}$, получаем, что сверхлитостатическое давление $\left(\Delta P_{\kappa}\right)$, обусловленное архимедовой силой расплава в канале плюма, много меньше $\Delta P_{\text {гп }}$ и поэтому им можно пренебречь.

При постоянной тепловой мощности, передаваемой от подошвы плюма в его канал $\left(N=\mathrm{Ka} N_{1}=\right.$ =const), объем $\Delta V$ магматического расплава, внедряющегося в единицу времени в массив над грибообразной головой плюма под действием сверхлитостатического давления $\Delta P_{\text {гп }}$, определяется из соотношений (1) и (6):

$$
\Delta V=\beta N / \rho C .
$$

Вероятно, большая масса магмы вдавливается в наименее прочных местах в более древние породы, раздвигая их в стороны при своем движении вверх. Так, под действием сверхлитостатического давления в расплаве у кровли плюма $\Delta P_{\text {гп }}$, определяемого из соотношения (16), может происходить выдавливание магмы в местах разломов корового массива над головой плюма, и объемный расход магмы дается соотношением (17). При закрытии, «заваривании» разлома под действием сверхлитостатического давления в массиве над головой плюма образуется другой разлом и происходит внедрение магмы в месте нового разлома и т.д.

В табл. 1 представлены параметры некоторых плюмов Северной Азии, создающих грибообразную голову. Расчеты проведены для следующих значений параметров: $\Delta T=440{ }^{\circ} \mathrm{C}, \Delta T_{\mathrm{s}}=10{ }^{\circ} \mathrm{C}, \rho_{0}=4500$ кг $/ \mathrm{M}^{3}, \quad a=\lambda / C \rho_{0}=1.3 \cdot 10^{-6} \quad \mathrm{M}^{2} / \mathrm{c}, \quad \rho=3000 \quad \kappa г / \mathrm{M}^{3}, \quad \lambda=$ $=7 \mathrm{BT} / \mathrm{M}^{\circ}{ }^{\circ} \mathrm{C}, \quad \beta=10^{-5}{ }^{\circ} \mathrm{C}-1 \quad$ с учетом геологических данных [Kuzmin et al., 2010] (возрастной интервал для магматических областей, площадь $S$, объем магматического расплава $V$ ).

Из табл. 1 следует, что время активной деятельности плюмов с грибообразной головой, или, другими словами, время образования батолитов составляет 20-30 млн лет. Массовый расход расплава, выдавливаемого в коровый слой, для различных батолитов составляет 634-815 кг/с. Относительная тепловая мощность «батолитовых» плюмов изменяется незначительно и составляет величину $\mathrm{Ka}=5.5-7.0$, а тепловая мощность на подошве плюма $N=7.6 \cdot 10^{10}-9.8 \cdot 10^{10}$ Вт. Толщина корового слоя над головой плюма $\delta=5.4-7.7$ км. Диаметр подошв плюмов 29-33 км, голов плюмов 357-437 км.

Из геологических данных (например [Kuzmin et al., 2010]) следует, что область распространения таких крупнейших батолитов, как Хангайский и Хэнтэйский, не осесимметричная. Ее наибольший размер $d_{r}{ }^{\prime}$ наблюдается в долготном направлении, а наименьший $d_{\Gamma} "$ - в широтном [Kirdyashkin et al., 2017]. Например, для Хангайского батолита $d_{\mathrm{r}}{ }^{\prime} \approx 740$ км, $d_{\Gamma}{ }^{\prime \prime} \approx 317$ км и отношение $d_{\Gamma^{\prime}}{ }^{\prime} d_{\Gamma^{\prime}}{ }^{\prime \prime} \approx 2.3$. Для Хэнтэйского батолита $d_{\mathrm{r}}{ }^{\prime} \approx 700$ км, $d_{\mathrm{r}}{ }^{\prime \prime} \approx 224$ км и $d_{\Gamma^{\prime}} / d_{\Gamma}{ }^{\prime \prime} \approx 3.1$. Вытянутость батолитов в долготном направлении, вероятно, связана с влиянием силы Кориолиса, которая проявляется при относительно низкой величине кинематической вязкости расплава $v=1-10 \mathrm{~m}^{2} / \mathrm{c}$.

\section{T а б л и ц а 1. Параметры некоторых плюмов, образующих грибообразную голову}

\begin{tabular}{|c|c|c|c|c|c|c|c|c|c|}
\hline \multicolumn{5}{|c|}{ Геологические данные } & \multicolumn{5}{|c|}{ Параметры плюмов } \\
\hline $\begin{array}{l}\text { № } \\
\text { п/п }\end{array}$ & $\begin{array}{l}\text { Магматическая провинция или } \\
\text { область }\end{array}$ & $\Delta t$, млн лет & $S \cdot 10^{3}$, км$^{2}$ & $V \cdot 10^{3}, \mathrm{\kappa м}^{3}$ & $\Delta G$, кг/с & $N, \mathrm{~B}$ T & $\mathrm{Ka}$ & $d$, км & $d_{\Gamma}$, км \\
\hline 1 & Баргузин-Витимская КМП & $\begin{array}{l}310-275 \\
(25)\end{array}$ & $\sim 150$ & $\sim 300$ & 815 & $9.8 \cdot 10^{10}$ & 7.0 & 33 & 437 \\
\hline 2 & Хангайский батолит & $\begin{array}{l}266-242 \\
(22)\end{array}$ & $>100$ & $>200$ & 793 & $9.5 \cdot 10^{10}$ & 6.8 & 32.5 & 357 \\
\hline 3 & Хэнтэйский батолит & $\begin{array}{l}225-195 \\
(30)\end{array}$ & $>100$ & $>200$ & 634 & $7.6 \cdot 10^{10}$ & 5.5 & 29 & 357 \\
\hline
\end{tabular}

$\mathrm{T}$ a b l e 1. Parameters of some plumes with mushroom-shaped heads 
Голова плюма симметрична относительно плоскости, проходящей через ось канала плюма (см. рис. 3). Осевая симметрия головы плюма возможна при ее диаметре $d_{r}$, соизмеримом с $d$, т.е. когда относительная тепловая мощность Ка несколько больше чем 1.9. В первом приближении будем рассматривать каждую из симметричных частей головы плюма как горизонтальный слой толщиной $l$. Горизонтальный размер слоя равен $d_{r^{\prime}} / 2$, ширина слоя равна $d_{r}$ ". При оценке толщины слоя $l$ толщину массива над кровлей плюма $\delta$ можно принять равной 5 км.

Толщину слоя расплава в голове плюма, образующегося при плавлении корового слоя, определим при следующих приближениях. Принимаем значение температуры расплава у кровли плюма $T_{\mathrm{p}}=1410^{\circ} \mathrm{C}$. При этой температуре пироксены, ильменит, магнетит и апатит представляют собой твердые взвеси в расплаве головы плюма (см. ниже). Содержание плагиоклаза в коровом слое более 45 \% [Voitkevich et al., 1990], и его температура плавления ниже, чем $T_{\mathrm{p}}$. Нормативное содержание плагиоклазового компонента в слое расплава с вышеуказанными твердыми взвесями равно $61.5 \%$, ортоклазового - Or=16.8 \% (см. раздел 7). Нормативный кварц Qtz=18.7 \% (см. там же) находится в расплаве во взвешенном (кристаллическом) состоянии. Доля плагиоклазового компонента в расплаве велика - она равна 0.72, поэтому в первом приближении глубину проплавления корового слоя в континентальной области определим по диаграмме плавкости двухкомпонентной системы альбит $\left(\mathrm{Ab}_{1}\right)$ - анортит $\left(\mathrm{An}_{1}\right)$, где $\mathrm{Ab}_{1}=$ $=A b /(A b+A n), A n_{1}=A n /(A b+A n), A b$ и An - весовое процентное содержание альбита и анортита в проплавляемом коровом слое. Таким образом, вместо диаграммы плавкости системы альбит - анортит ортоклаз будем использовать приближение диаграммы плавкости системы альбит - анортит, представленной в относительных координатах $\mathrm{Ab}_{1}-\mathrm{An}_{1}$. Идея использования подобного приближения для диаграмм плавкости при рассмотрении многокомпонентных систем предложена В.С. Соболевым [Sobolev, 1986].

На рис. 4 представлена диаграмма плавления плагиоклазов при различных давлениях. Диаграмма плавкости системы альбит - анортит при давлении, равном 1 атмосфере (1 бар), представлена по [Bowen, 1913]. Для других давлений диаграмма построена следующим образом: зная температуры плавления альбита и анортита при соответствующих давлениях [Gramenitsky et al., 2000], переносим линии солидуса и ликвидуса, соответствующие давлению, равному 1 атмосфере. Перенос осуществляется так. Зная диаграмму плавкости $\mathrm{Ab}-\mathrm{An}$ для $P_{1}=1$ бар, при относительно

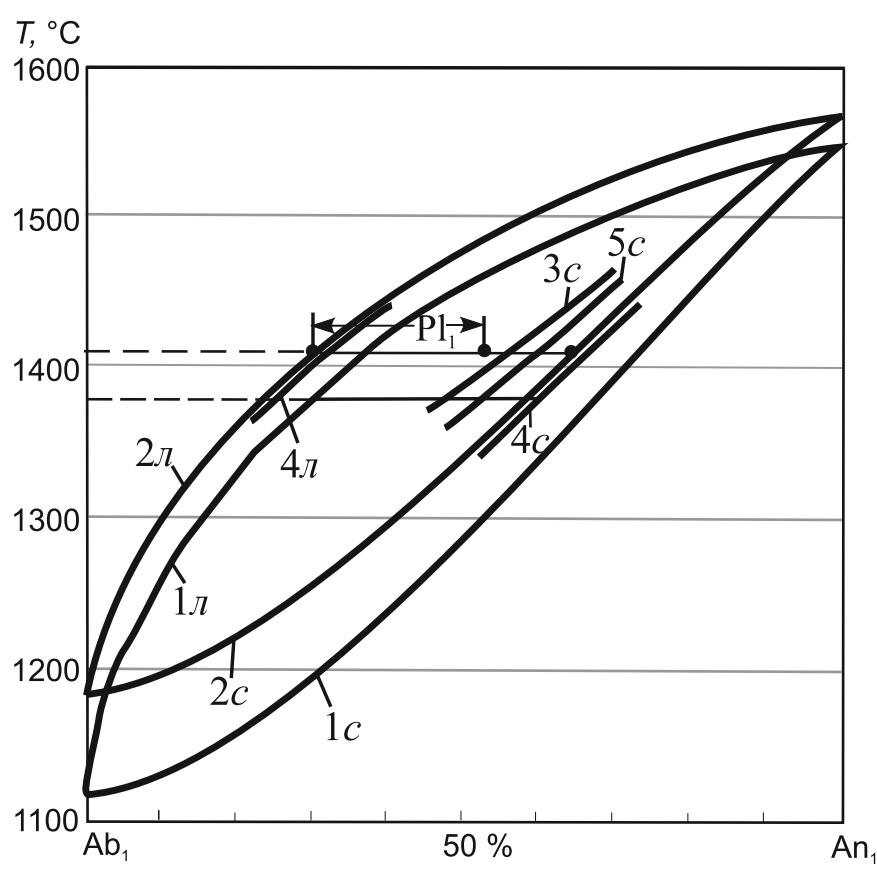

Рис. 4. Фазовая диаграмма плагиоклазов при различных давлениях.

$1 c$ - солидус при $P=1$ бар; $1 л-$ ликвидус при $P=1$ бар [Bowen, 1913]; $2 c$ - солидус при $P=6.3$ кбар; $2 л-$ ликвидус при $P=6.3$ кбар; $3 c$ - солидус при $P=12$ кбар; $4 c$ - солидус при $P=5$ кбар; $4 л$ - ликвидус при $P=5$ кбар; $5 c$ - солидус при $P=10$ кбар.

Fig. 4. Phase diagram of plagioclase feldspars for different pressure rates.

$1 c$ - solidus at $P=1$ bar; $1 \Omega$ - liquidus at $P=1$ bar [Bowen, 1913]; $2 c$ - solidus at $P=6.3 \mathrm{kbar} ; 2 \Omega-$ liquidus at $P=6.3 \mathrm{kbar} ; 3 c-$ solidus at $P=12 \mathrm{kbar} ; 4 c$ - solidus at $P=5 \mathrm{kbar} ; 4 \Omega$ - liquidus at $P=5 \mathrm{kbar} ; 5 c-$ solidus at $P=10 \mathrm{kbar}$.

малом изменении давления (до 6 бар) диаграмму для $P_{2}>P_{1}$ определяем в первом приближении по соотношениям: $T_{л, 2}=T_{л, 1}+\Delta T_{\mathrm{Ab}}-\left(\Delta T_{\mathrm{Ab}}-\Delta T_{\mathrm{An}}\right) \cdot \mathrm{An} \cdot 10^{-2}$; $T_{\mathrm{c}, 2}=T_{\mathrm{c}, 1}+\Delta T_{\mathrm{Ab}}-\left(\Delta T_{\mathrm{Ab}}-\Delta T_{\mathrm{An}}\right) \cdot \mathrm{An} \cdot 10^{-2}$, где $T_{л, 1}$ и $T_{\mathrm{c}, 1}-$ температуры ликвидуса и солидуса для значения An (\%) при давлении $P_{1}, T_{\pi, 2}$ и $T_{c, 2}$ - температуры ликвидуса и солидуса для того же значения An (\%) при давлении $P_{2}, \Delta T_{\mathrm{Ab}}=T_{2, \mathrm{Ab}}-T_{1, \mathrm{Ab}}-$ разность температур плавления для $\mathrm{Ab}(100 \%)$ при $P_{2}$ и $P_{1}$, $\Delta T_{\mathrm{An}}=T_{2, \mathrm{An}}-T_{1, \mathrm{An}}-$ разность температур плавления для An $(100 \%)$ при $P_{2}$ и $P_{1}$.

Приведем пример определения толщины расплавленного слоя $l$, образовавшегося в результате плавления континентальной коры (см. рис. 3). Для $T_{\mathrm{p}}=1410{ }^{\circ} \mathrm{C}$ и состава расплава, отвечающего N $57\left(\mathrm{An}_{1}=57 \%\right)$, плавление невозможно уже при $P=12$ кбар (рис. 4, кривая 3c), т.е. глубина проплавления коры составляет $l_{\text {кор }}=36$ км, и тогда для $\delta=5$ км толщина слоя расплава головы плюма $l=l_{\text {кор }}-\delta=31$ км. Для $T_{\mathrm{p}}=1380{ }^{\circ} \mathrm{C}$ и состава расплава, отвечающего N $53\left(\mathrm{An}_{1}=53 \%\right)$, плавление невоз- 
можно при $P=10$ кбар (рис. 4, кривая $5 c$ ), т.е. $l_{\text {кор }}=30$ км, и тогда $l=25$ км. При нашей точности оценок получается, что толщина слоя расплава головы плюма $l$ соизмерима с диаметром его канала $d$. Долю твердой фазы в расплаве можно установить, зная его нормативный состав. Последний можно определить, зная весовое процентное содержание оксидов в коровом слое.

Как видим, исследование гидродинамики и теплообмена в грибообразной голове плюма тесно связано с необходимостью исследования фазового состава расплава в ней. Сложность задачи вынуждает проводить исследования методом последовательного приближения. Прежде всего оценим, как изменяется температура в объеме расплава головы плюма.

Как было указано ранее, в первом приближении будем рассматривать голову плюма в виде плоского слоя толщиной $l$, длиной $d_{\mathrm{r}}{ }^{\prime}$ и шириной $d_{\mathrm{r}}{ }^{\prime \prime}$. Голова плюма состоит из двух симметричных горизонтальных слоев длиной $0.5 d_{\mathrm{r}}$ '. Тепловая мощность, подводящаяся к голове плюма в плоскости симметрии двух слоев, равна $\Delta N$, и, следовательно, тепловая мощность, подводящаяся к каждому слою, равна $0.5 \Delta N$. Отвод тепла осуществляется от кровли головы плюма, температура которой $T_{\mathrm{r}}=$ const. Экспериментальные и теоретические исследования свободно-конвективных течений в горизонтальном слое жидкости при указанных условиях показывают, что максимальное значение разности температуры между расплавом и охлаждаемой верхней горизонтальной поверхностью в области подъемного потока расплава в канале плюма определяется из соотношения:

$$
\Delta T_{\max }=T_{\mathrm{p}}-T_{\mathrm{r}}=(7.07 Q / \lambda) \mathrm{Ra}_{Q^{-1 / 3}},
$$

где $Q=\Delta N / 2 d_{\text {г }}{ }^{\prime \prime}$ - тепловая мощность, подводимая на один погонный метр (Вт/м), $\lambda$ - коэффициент теплопроводности расплава, $\mathrm{Ra}_{Q}=\beta g Q l^{3} / a v \lambda$ - число Рэлея [Kirdyashkin et al., 2017].

Максимальная скорость свободно-конвективного течения имеет постоянное значение вдоль слоя, и ее величина определяется из соотношения:

$$
u_{\max }=0.707(a / l) \operatorname{Ra}_{Q^{1 / 3}} .
$$

Среднее значение горизонтальной скорости течения $\bar{u}=0.42 u_{\max }$ [Kirdyashkin et al., 2017].

Оценим величины $\Delta T_{\max }$ и $u_{\max }$ для Хэнтэйского плюма. Для него $N=7.6 \cdot 10^{10}$ Вт (табл. 1) и, согласно равенству (10), $\Delta N=6 \cdot 10^{10} \mathrm{BT}$. Тогда $Q=1.34 \cdot 10^{5} \mathrm{BT} / \mathrm{M}$ для $d_{\Gamma} "=224$ км. Для $l=d=2.9 \cdot 10^{4}$ м (табл. 1 ), $\lambda=3.5$ $\mathrm{BT} / \mathrm{M} \cdot{ }^{\circ} \mathrm{C}, v=1-10 \mathrm{M}^{2} / \mathrm{c}, \beta=10^{-5}{ }^{\circ} \mathrm{C}^{-1}$ и $a=10^{-6} \mathrm{M}^{2} / \mathrm{c}$ получаем $\operatorname{Ra}_{Q}=9.2 \cdot 10^{18}-9.2 \cdot 10^{19}$.

При выплавлении головы плюма в коровом слое, как указано ниже, доля нерасплавившихся минералов составляет $1 / 3$ от общего состава этого слоя. В этом случае твердых взвесей в расплаве будет около 30 \%. Тогда вязкость расплава возрастает приблизительно в три раза [Persikov, 1984], т.e. эффективная кинематическая вязкость расплава будет $v_{э \phi}=3-30 \mathrm{~m}^{2} /$ с. Соответствующее число Рэлея $\mathrm{Ra}_{Q}=3.1 \cdot 10^{18}-3.1 \cdot 10^{19}$. Тогда, согласно соотношениям (18) и (19), в период выплавления головы плюма $\Delta T_{\max }=0.10-0.21^{\circ} \mathrm{C}, u_{\max }=3.5 \cdot 10^{-5}-7.6 \cdot 10^{-5} \mathrm{M} / \mathrm{c}$. Средняя скорость течения в верхней и нижней части слоя расплава $\bar{u}=1.5 \cdot 10^{-5}-3.2 \cdot 10^{-5} \mathrm{M} / \mathrm{c}$. Вследствие малых сверхадиабатических перепадов температуры в расплаве головы плюма $\Delta T_{\max }$ температура расплава $T_{\mathrm{p}}$ оказывается примерно равной температуре плавления $T_{\text {пл }}$ материала головы плюма.

Структура течения в расплаве сформированной головы плюма представлена на рис. 5 на основе данных лабораторного моделирования [Kirdyashkin et al., 2017]. Восходящее свободно-конвективное течение расплава проявляется вдоль оси канала плюма. Восходящий поток набегает на кровлю головы плюма, происходит его растекание от лобовой точки вдоль кровли головы плюма, и затем в канал плюма уходят два нисходящих потока (рис. 5). Существуют горизонтальные потоки вдоль верхней и нижней границы зоны расплава в голове плюма. Крупномасштабные свободно-конвективные течения в расплаве головы плюма возникают из-за горизонтального градиента температуры в нем. В верхней части (у кровли головы плюма) горизонтальные течения имеют нестабильный характер из-за условий неустойчивой стратификации и неустойчивых валиковых течений у кровли плюма. Горизонтальные крупномасштабные течения у подошвы плюма (в нижней части зоны расплава) происходят в условиях устойчивой стратификации из-за теплоотвода в массив под подошвой грибообразной головы плюма. В связи с этим течения здесь имеют устойчивый характер и могут благоприятствовать процессам кристаллизационной дифференциации. Расплав, выдавленный в вышележащий массив под действием силы сверхлитостатического давления $\Delta P$, замещается расплавом из подъемного потока канала под кровлей грибообразной головы плюма (рис. 5).

В расплаве грибообразной головы плюма могут находиться твердые взвеси тугоплавких минералов, имеющих более высокую температуру плавления и более высокую плотность, чем расплав. При стационарном режиме теплообмена, когда количество тепла, подведенного к голове плюма, равно количеству тепла, переданного к дневной поверхности, частицы взвесей будут осаждаться в расплаве под действием силы тяжести. Таким образом, на подошве головы плюма может сформироваться 


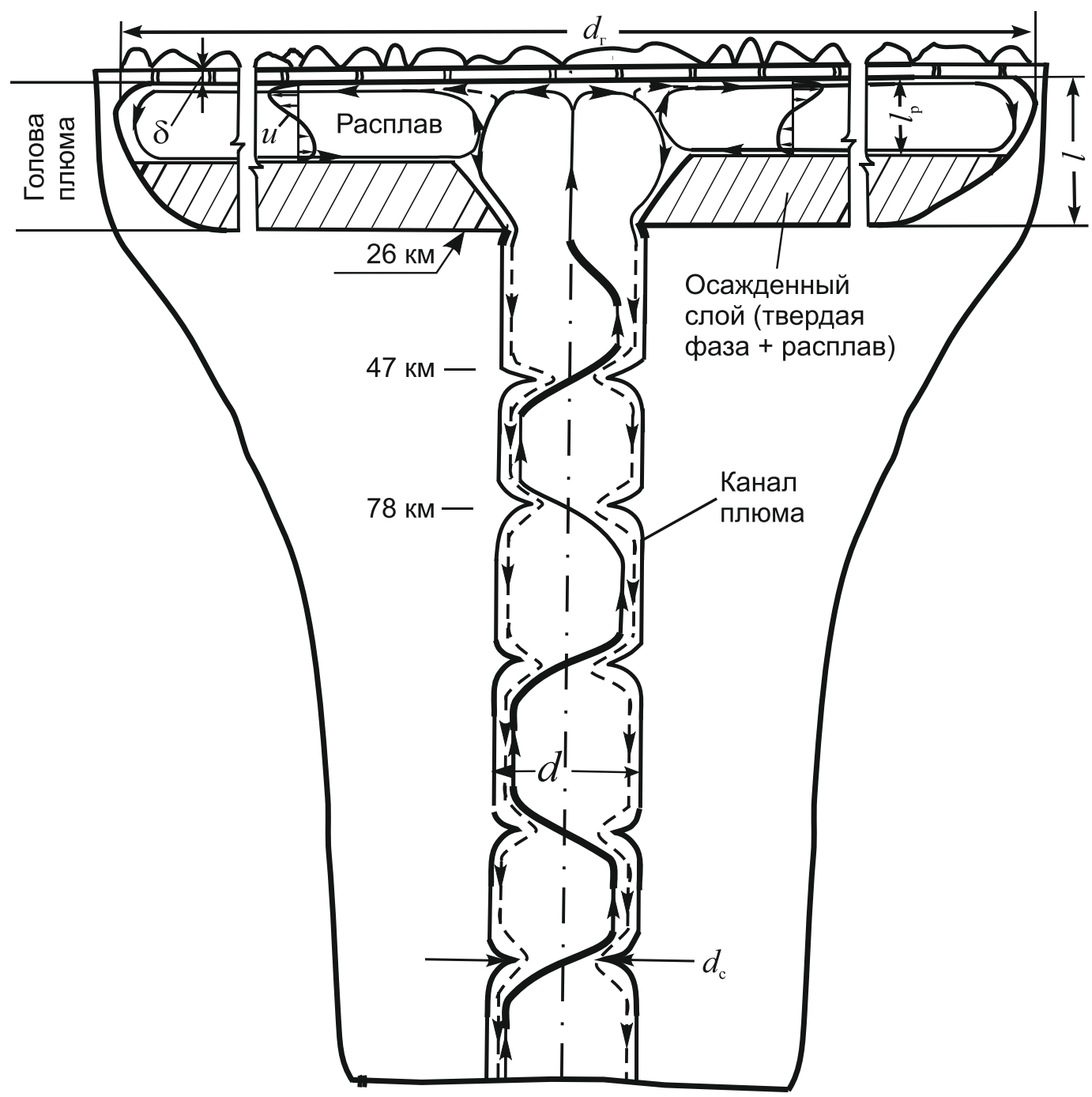

Рис. 5. Схема термохимического плюма и свободно-конвективных течений в расплаве канала и грибообразной головы плюма, построенная с учетом данных лабораторного моделирования [Kirdyashkin et al., 2017]. Схема выполнена в масштабе относительно диаметра канала плюма $d$ для Хэнтэйского батолита. Размеры канала и головы плюма на схеме соответствуют рассчитанным размерам для Хэнтэйского плюма. Показаны уровни (км), отвечающие первым двум конвективным ячейкам канала плюма.

Fig. 5. Schematic of the thermochemical plume and free-convection flows in the melt of the plume conduit and the mushroom-shaped plume head, constructed with regard to the data of laboratory modeling [Kirdyashkin et al., 2017]. Schematic is in the scale relative to the plume conduit diameter $(d)$ of the Khentei batholith. In this figure, the sizes of the plume conduit and the plume head correspond to the sizes calculated for the Khentei plume. The levels (km) corresponding to the first two convective cells of the plume conduit are shown.

слой, слагаемый осажденными нерасплавленными взвесями (рис. 5). В межкристаллических пространствах этого слоя остается расплав, объем которого составляет $26 \%$ от объема осажденных твердых тугоплавких частиц (в приближении сферической упаковки) [Nekrasov, 1973]. Эта величина является минимальной, в случае отклонения от сферической упаковки она возрастает [Nekrasov, 1973].

Согласно вышеприведенным оценкам, сверхадиабатические перепады температуры в грибообразной голове плюма составляют $\sim 0.2{ }^{\circ} \mathrm{C}$, поэтому на процессы кристаллизационной дифференциации в большей степени должно влиять изменение давления по высоте слоя вследствие изменения диаграммы плавкости плагиоклазов с давлением (см. рис. 4). При постоянном значении количества тепла, поступающего к голове плюма ( $\Delta N=$ const) в течение 20-30 млн лет в голове плюма существуют благоприятные условия для осаждения твердой фазы.

Время выплавления грибообразной головы плюма (время проплавления слоя коры) $t_{\text {пл }}$ (см. рис. 3 ) можно оценить из соотношения: 


$$
t_{\text {пл }}=\rho_{\text {кор }} V_{\text {г }}[C \Delta T+B(1-\varphi)] /(\Delta N / 2),
$$

где $\rho_{\text {кор }}$ - плотность корового слоя, $V_{\text {г }}$ - объем головы плюма, $C \Delta T$ - тепло, затрачиваемое на нагрев до температуры плавления, $B$ - теплота плавления, $\varphi$ - доля твердой фазы в расплаве. Например, для Хэнтэйского плюма $V_{\Gamma}=2.55 \cdot 10^{15} \mathrm{M}^{3}, \Delta N=6 \cdot 10^{10}$ Вт. Для этих значений и для $\Delta T=440{ }^{\circ} \mathrm{C}, C=1.1 \cdot 10^{3}$ Дж/кг ${ }^{\circ} \mathrm{C}, B=2.1 \cdot 10^{5}$ Дж/кг, $\rho_{\text {кор }}=3000$ кг $/ \mathrm{M}^{3}, \varphi=0.5$ получаем время проплавления $t_{\text {пл}}=1.5 \cdot 10^{14} \mathrm{c}=4.8$ млн лет. Время образования батолитов много больше, чем время выплавления грибообразной головы плюма. В процессе выплавления головы плюма также происходит осаждение более тяжелых частиц тугоплавких минералов.

\section{7. РАСЧЕТ СОСТАВА СЛОЯ РАСПЛАВА И ОСАЖДЕННОГО СЛОЯ НА ОСНОВЕ ЗАКОНОМЕРНОСТЕЙ ТЕПЛО- И МАССООБМЕНА В РАСПЛАВЕ ГОЛОВЫ ПЛЮМА И ДИАГРАММЫ ПЛАВКОСТИ ПЛАГИОКЛАЗА}

В первом приближении мы уже оценили величины изменения температуры и скорости в голове плюма. При расчетах состава будем основываться на анализе процессов тепло- и массообмена для случая, когда грибообразная голова плюма достигает своего наибольшего размера, т.е. в установившихся условиях.

Изменение состава расплава будем определять поэтапно:

1) после осаждения тугоплавких минералов;

2) после осаждения плагиоклаза в расплаве, образовавшемся после первого этапа и содержащем 61.5 \% плагиоклазового компонента (табл. 2, столбец 4, нижний ярус).

Анализ будем проводить, используя оценки среднего химического состава континентальной коры по А. Ронову и А. Ярошевскому [Voitkevich et al., 1990] (табл. 2, столбец 2, верхний ярус). Пересчет химического состава расплава головы плюма на нормативный состав осуществляется с использованием таблицы MS Excel (автор: G. Stern, Орлеан, Франция), созданной для пересчета по методу CIPW, первоначально разработанному в [Cross et al., 1902].

Определим состав расплава после осаждения нерасплавленных (тугоплавких) минералов.

При температуре расплава, поступающего из канала к кровле плюма, равной $T_{\mathrm{p}}=1410{ }^{\circ} \mathrm{C}$, в виде твердых взвесей в расплаве головы плюма остаются минералы (в пересчете на нормативный состав по вышеуказанной расчетной таблице): диопсид (Di) - $8.88 \%$, гиперстен (Нyp) - $15.21 \%$, магнетит (Mgt) - $3.48 \%$, ильменит (Ilm) - $1.33 \%$, апатит (Ap) - 0.46 \% (табл. 2, столбец 2, нижний ярус). Суммарное массовое содержание указанных тугоплавких минералов в голове плюма равно $29.4 \%$. Плотность этих минералов ( $\rho_{\text {Hyp }}=3.3-3.5 \quad г / \mathrm{cm}^{3} ; \quad \rho_{\text {Di }}=3.27-$ $3.38 г / \mathrm{cm}^{3} ; \quad \rho_{\mathrm{Mgt}}=4.8-5.3 \Gamma / \mathrm{cm}^{3} ; \quad \rho_{\mathrm{Ilm}}=4.6-4.8 \Gamma / \mathrm{cm}^{3}$; $\rho_{\text {Ap }}=3.1-3.2 г / \mathrm{cm}^{3}$ ) (например [Vertushkov, Avdonin, 1992]) больше плотности расплава, представляющего собой расплав, содержащий ортоклазовый

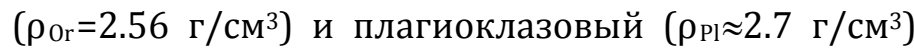
[Vertushkov, Avdonin, 1992; Frye, 1983] компоненты. С учетом того, что среди осаждающихся тугоплавких минералов большую долю составляют нормативные пироксены (согласно расчетной таблице, диопсид и гиперстен), в среднем плотность осажденных минералов больше плотности расплава примерно на $25 \%$, вследствие этого произойдет осаждение более плотных кристаллитов вышеуказанных тугоплавких минералов на подошву головы плюма. Возможные скорость и время осаждения оценены в разделе 8.

Также в виде твердой фазы в расплаве остается нормативный кварц Qtz $\left(\mathrm{SiO}_{2}\right)=13.57$ \% (табл. 2, столбец 2). При температуре расплава в голове плюма $T_{\mathrm{p}}=1410{ }^{\circ} \mathrm{C} \mathrm{SiO}_{2}$ может существовать в виде тридимита [Brückner, 2003]. Так как температура плавления тридимита $\left(1670 \pm 10{ }^{\circ} \mathrm{C}\right)$ выше температуры расплава, а плотность тридимита $\left(\rho_{\mathrm{Tr}}=2.22-\right.$

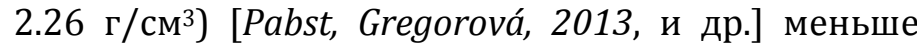
плотности расплава, указанная твердая фаза будет всплывать к кровле плюма и находиться во взвешенном состоянии в свободно-конвективных течениях в расплаве головы плюма.

Следующая задача состоит в определении процентного содержания оксидов, составляющих осажденные из расплава твердые взвеси. Приведем пример определения процентного содержания оксидов в диопсиде Di, процентное содержание которого в расплаве головы плюма равно 8.88 \%. Химическая формула диопсида может быть представлена в виде оксидов: $\mathrm{CaO} \cdot \mathrm{MgO} \cdot 2 \mathrm{SiO}_{2}$. Результаты расчетов процентного содержания для каждого оксида представлены в табл. 3. Для каждого оксида во втором столбце указан его молекулярный вес $M_{\text {ох }}$. Суммирование молекулярных весов соответствующих оксидов дает молекулярный вес диопсида $M_{\mathrm{Di}}$. В третьем столбце приведено относительное содержание каждого оксида, представляющее отношение молекулярного веса соответствующего оксида к молекулярному весу диопсида $\left(M_{\mathrm{ox}} / M_{\mathrm{Di}}\right)$. В четвертом столбце - процентное содержание каждого оксида, полученное посредством умножения отношения $M_{\text {ox }} / M_{\text {Di }}$ на процентное содержание диопсида. В табл. 4 представлено определение процентного содержания оксидов в осажденном гиперстене (Нур), содержание которого в расплаве головы плюма равно 15.21 \%. Для него имеем формулу ( $\mathrm{Mg}, \mathrm{Fe})_{2} \mathrm{Si}_{2} \mathrm{O}_{6}(\mathrm{Fe}=50 \%)$ и в оксидной форме: $\mathrm{MgO} \cdot \mathrm{FeO} \cdot 2 \mathrm{SiO}_{2}$. 


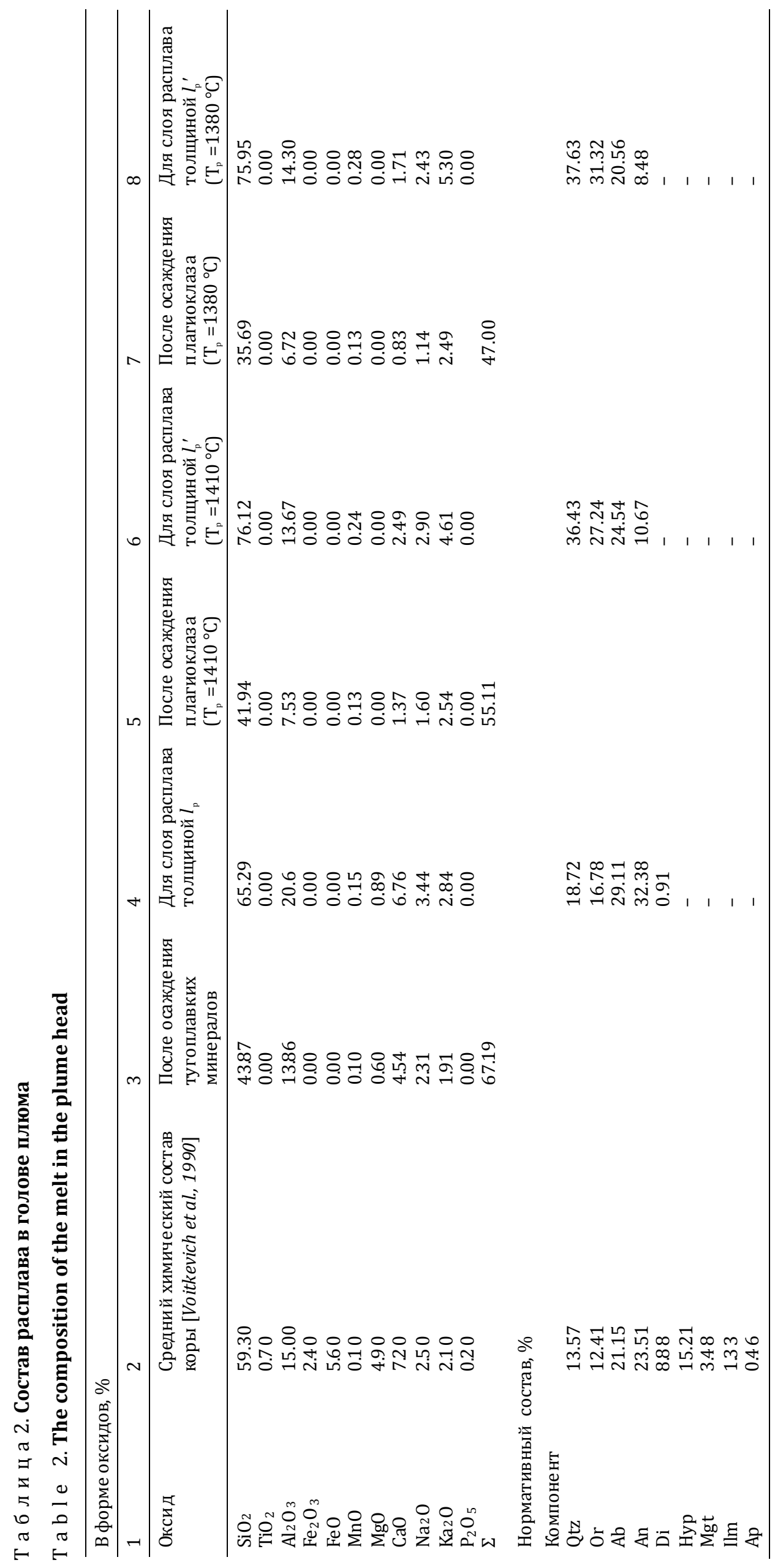


Т а б л и ц а 3. Содержание оксидов в осажденном диопсиде (Di)

$\mathrm{T}$ a b l e 3 . The oxide content in the settled diopside (Di)

\begin{tabular}{llll}
\hline Оксид & $M_{\text {ox }}$ & $M_{\text {ох }} / M_{\text {Di }}$ & $\left(M_{\text {ox }} / M_{\mathrm{Di}}\right) \times 8.88 \%$ \\
\hline $\mathrm{CaO}$ & 56.08 & 0.26 & 2.30 \\
$\mathrm{MgO}$ & 40.31 & 0.19 & 1.65 \\
$2 \mathrm{SiO}_{2}$ & 120.17 & 0.55 & 4.88 \\
\hline
\end{tabular}

Таким же образом с использованием расчетной таблицы определяется содержание оксидов в $\mathrm{Im}$ $\left(\mathrm{FeO} \cdot \mathrm{TiO}_{2}, 1.33 \%\right): \mathrm{FeO}(0.63 \%), \mathrm{TiO}_{2}(0.7 \%)$ и $\mathrm{Mgt}$ ( $\mathrm{FeO} \cdot \mathrm{Fe}_{2} \mathrm{O}_{3}, 3.48 \%$ ): $\mathrm{FeO}(1.08 \%), \mathrm{Fe}_{2} \mathrm{O}_{3}(2.4 \%)$.

Исходя из указанных расчетов, суммарное содержание для каждого оксида будет: $\mathrm{SiO}_{2}-12.09 \%$, $\mathrm{FeO}-6.41 \%, \mathrm{Fe}_{2} \mathrm{O}_{3}-2.40 \%, \mathrm{CaO}-2.3 \%, \mathrm{MgO}-$ $4.30 \%, \mathrm{TiO}_{2}-0.7 \%$.

В сумме осажденные тугоплавкие минералы составляют 29.36 \% (см. табл. 2, столбец 2). Для расплава, с учетом тугоплавких минералов, пересчет на нормативный состав дает: Or (12.41\%), Ab (21.15 \%), An (23.11 \%) и, возможно, Qtz (13.57 \%) (см. табл. 2, столбец 2). Как указано выше, в межкристаллическом пространстве слоя, слагаемого осажденными тугоплавкими минералами, остается $26 \%$ расплава [Nekrasov, 1973]. Для определения весового содержания расплава в межкристаллических пространствах осажденного слоя принимаем, что в первом приближении объем осажденного слоя составляет 29.36 \% от объема головы плюма. Весовое содержание расплава в межкристаллическом пространстве осажденного слоя составит $0.26 \times 29.36=$ $=7.63 \%$. Тогда для расплава, находящегося в межкристаллических пространствах осажденного слоя, указывая для каждого компонента в скобках формулы в виде оксидов, получаем:

Qtz $\left(\mathrm{SiO}_{2}\right)=0.076 \times 13.57 \%=1.03 \%$;

Or $\left(\mathrm{K}_{2} \mathrm{O} \cdot \mathrm{Al}_{2} \mathrm{O}_{3} \cdot 6 \mathrm{SiO}_{2}\right)=0.076 \times 12.41 \%=0.95 \%$;

$\mathrm{Ab}\left(\mathrm{Na}_{2} \mathrm{O} \cdot \mathrm{Al}_{2} \mathrm{O}_{3} \cdot 6 \mathrm{SiO}_{2}\right)=0.076 \times 21.15 \%=1.61 \%$;

$\mathrm{An}\left(\mathrm{CaO} \cdot \mathrm{Al}_{2} \mathrm{O}_{3} \cdot 2 \mathrm{SiO}_{2}\right)=0.076 \times 23.11 \%=1.79 \%$.

Процентное содержание оксидов, оставшихся в межкристаллических пространствах осажденного

\section{T а б л и ц а 4. Содержание оксидов в осажденном гиперстене (Нур)}

$\mathrm{T}$ a b l e 4 . The oxide content in the settled hyperstene (Hyp)

\begin{tabular}{llll}
\hline Оксид & $M_{\text {ox }}$ & $M_{\text {ox }} / M_{\text {Hур }}$ & $\left(M_{\text {ox }} / M_{\text {Hур }}\right) \times 15.21 \%$ \\
\hline $\mathrm{MgO}$ & 40.31 & 0.17 & 2.59 \\
$\mathrm{FeO}$ & 71.84 & 0.31 & 4.70 \\
$2 \mathrm{SiO}_{2}$ & 120.17 & 0.52 & 7.91 \\
\hline
\end{tabular}

слоя, представлено в табл. 5-7. Суммарное процентное содержание оксидов, оставшихся в межкристаллических пространствах осажденного слоя: $\mathrm{SiO}_{2}-3.34 \%, \mathrm{Al}_{2} \mathrm{O}_{3}-1.14 \%, \mathrm{CaO}-0.36 \%, \mathrm{Na}_{2} \mathrm{O}-$ $0.19 \%, \mathrm{~K}_{2} \mathrm{O}-0.19 \%$. Суммарное значение процентного содержания каждого оксида для осажденных минералов и для расплава в межкристаллических пространствах: $\mathrm{SiO}_{2}-15.43 \%, \mathrm{TiO}_{2}-0.7 \%, \mathrm{Al}_{2} \mathrm{O}_{3}-$ $1.14 \%, \mathrm{Fe}_{2} \mathrm{O}_{3}-2.4 \%, \mathrm{FeO}-6.4 \%, \mathrm{MgO}-4.3 \%, \mathrm{CaO}-$ $2.66 \%, \mathrm{Na}_{2} \mathrm{O}-0.19 \%, \mathrm{~K}_{2} \mathrm{O}-0.19 \%, \mathrm{P}_{2} \mathrm{O}_{5}-0.2 \%$. Toгда в пересчете на оксиды процентное содержание твердых взвесей и расплава, захваченного в межкристаллических пространствах, составляет $33.61 \%$, и поэтому толщина слоя расплава $l_{\mathrm{p}}$, залегающего над осажденным слоем в голове плюма толщиной $l$ (рис. 5), будет $l_{\mathrm{p}}=l(1-0.336)=0.664 l$. Для $l=29-33$ км, $l_{\mathrm{p}}=(19.3-21.9)$ км.

Вычитая процентный состав соответствующего осажденного оксида (с учетом расплава в межкристаллических пространствах) из среднего состава континентальной коры (см. табл. 2, столбец 2, верхний ярус), получаем состав расплава (в форме оксидов) в голове плюма толщиной $l$, остающегося после осаждения тугоплавких минералов (см. табл. 2 , столбец 3 , верхний ярус). Например, содержание $\mathrm{SiO}_{2}$ в расплаве составляет $59.30 \%-15.43 \%=$ $=43.87 \%$. Аналогично получаем процентное содержание других оксидов в расплаве.

Перейдем от процентного содержания оксидов в слое расплава относительно содержания оксидов во всей голове плюма толщиной $l$ к процентному содержанию оксидов в слое расплава толщиной $l_{\mathrm{p}}$. Определим процентное содержание оксидов для слоя расплава толщиной $l_{\text {p. }}$ Для этого в табл. 2 суммируем столбец $3\left(\sum=67.19 \%\right)$ и затем умножим его на величину 100/67.19. Состав слоя расплава толщиной $l_{\mathrm{p}}$ (в форме оксидов) представлен в табл. 2 , столбец 4 (верхний ярус). Нормативный состав представлен в табл. 2, столбец 4 (нижний ярус): Or $(16.78 \%), \mathrm{Ab}(29.11 \%)$ и An (32.38 \%). Большую долю составляет плагиоклазовый компонент (61.49 \%). Нормативный кварц Qtz (18.72 \%) находится в расплаве в основном в виде твердой взвеси, поскольку выше было указано, что плотность тридимита меньше плотности расплава, а температура плавления тридимита выше, чем температура расплава.

Определение состава остаточного расплава, который существует после осаждения твердых взвесей плагиоклаза. Как было указано в разделе «Гидродинамика и теплообмен в грибообразной голове плюма», количество плагиоклазового компонента в расплаве, возникшем после осаждения тугоплавких минералов, будем определять по диаграмме плавления плагиоклаза для системы альбит-анортит $A b_{1}-A n_{1}$, где $\mathrm{Ab}_{1}=\mathrm{Ab} /(\mathrm{Ab}+\mathrm{An}), \mathrm{An}_{1}=$ 
Т а б л и ц а 5. Содержание оксидов в ортоклазе (Or), оставшемся в осажденном слое

$\mathrm{T}$ a b l e 5 . The oxide content in orthoclase (Or) remaining in the settled refractory minerals

\begin{tabular}{llll}
\hline Оксид & $M_{\text {ox }}$ & $M_{\text {ох }} / M_{\text {or }}$ & $\left(M_{\text {ox }} / M_{\text {or }}\right) \times 0.95 \%$ \\
\hline $\mathrm{K}_{2} \mathrm{O}$ & 94.20 & 0.17 & 0.19 \\
$\mathrm{Al}_{2} \mathrm{O}_{3}$ & 101.96 & 0.18 & 0.17 \\
$6 \mathrm{SiO}_{2}$ & 360.51 & 0.65 & 0.62 \\
\hline
\end{tabular}

T а б л и ц а 6. Содержание оксидов в альбите (Ab), оставшемся в осажденном слое

$\mathrm{T}$ a b l e 6. Table 6. The oxide content in albite (Ab) which remains with the settled refractory minerals

\begin{tabular}{llll}
\hline Оксид & $M_{\mathrm{ox}}$ & $M_{\mathrm{ox}} / M_{\mathrm{Ab}}$ & $\left(M_{\mathrm{ox}} / M_{\mathrm{Ab}}\right) \times 1.61 \%$ \\
\hline $\mathrm{Na}_{2} \mathrm{O}$ & 61.98 & 0.12 & 0.19 \\
$\mathrm{Al}_{2} \mathrm{O}_{3}$ & 101.96 & 0.19 & 0.31 \\
$6 \mathrm{SiO}_{2}$ & 360.51 & 0.69 & 1.11 \\
\hline
\end{tabular}

Т а б л и ц а 7. Содержание оксидов в анортите (An), оставшемся в осажденном слое

$\mathrm{T}$ a b l e 7. The oxide content in anorthite (An) remaining in the settled refractory minerals

\begin{tabular}{llll}
\hline Оксид & $M_{\text {ox }}$ & $M_{\text {ox }} / M_{\text {An }}$ & $\left(M_{\text {ox }} / M_{\text {An }}\right) \times 1.79 \%$ \\
\hline $\mathrm{CaO}$ & 56.08 & 0.20 & 0.36 \\
$\mathrm{Al}_{2} \mathrm{O}_{3}$ & 101.96 & 0.37 & 0.66 \\
$2 \mathrm{SiO}_{2}$ & 120.17 & 0.43 & 0.77 \\
\hline
\end{tabular}

$=A n /(A b+A n), A b$ и An - процентное содержание альбита и анортита в проплавляемом коровом слое (см. рис. 4). То есть в первом приближении предположим, что закономерности поведения системы $\mathrm{Ab}_{1}-\mathrm{An}_{1}$ для расплава после осаждения тугоплавких минералов такие же, как для системы $\mathrm{Ab}-\mathrm{An}$. Таким образом, в первом приближении принимаем, что присутствие в расплаве ортоклазового компонента Or (16.78 \%) существенно не скажется на закономерностях поведения диаграммы плавления альбит - анортит, представленной в относительных координатах $\mathrm{Ab}_{1}-\mathrm{An}_{1}$.

Как было показано выше, в голове плюма, моделируемой плоским слоем, сверхадиабатическая температура расплава постоянная с точностью $0.2^{\circ} \mathrm{C}$ в течение времени, отсчитываемого от начала плавления корового слоя. При температуре расплава $1410{ }^{\circ} \mathrm{C}$ закристаллизовавшийся плагиоклаз находится в химическом равновесии с расплавом. Однако в поле силы тяжести закристаллизовав- шийся плагиоклаз находится в расплаве в гидродинамически неустойчивом состоянии из-за различия в плотности расплава и закристаллизовавшегося плагиоклаза. Например, при $P=1$ бар, с

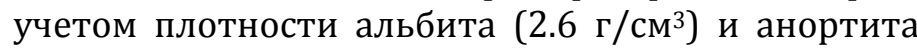

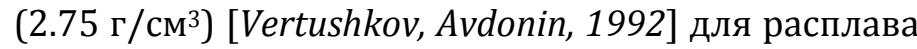
плагиоклаза N $30\left(\mathrm{An}_{1}=30 \%\right)$ (см. рис. 4, состав на линии ликвидуса) $\rho_{1}=2.65$ г $/ \mathrm{cm}^{3}$, а для плагиоклаза $\mathrm{N} 70\left(\mathrm{An}_{1}=70 \%\right)$ (см. рис. 4 , состав на линии солидуса) $\rho_{2}=2.71 \Gamma / \mathrm{cm}^{3}, \quad$ и разность плотностей $\Delta \rho=\rho_{2}-\rho_{1}=0.06 \Gamma / \mathrm{cm}^{3}$, т.е. различие в плотности составляет $2.2 \%$. Для сравнения, такое различие для мантийного вещества получится при перепаде температуры в $730{ }^{\circ} \mathrm{C}$ для коэффициента теплового объемного расширения $\beta=3 \cdot 10^{-5}{ }^{\circ} \mathrm{C}^{-1}$. Как показывают оценки времени осаждения (см. раздел 8), за время существования плюма, ответственного за образование крупного интрузивного тела (батолита) (20-30 млн лет) [Kirdyashkin A.G., Kirdyashkin A.A., 2016], должно произойти осаждение твердых взвесей плагиоклаза. Рассмотрим этот этап осаждения плагиоклаза.

В рассматриваемом нами случае на процессах осаждения твердых взвесей сказывается влияние гидродинамики и теплообмена, а также изменение с глубиной литостатического давления, которое проявляется через изменение диаграммы плавления плагиоклазов. Ранее указывалось, что в верхней части головы плюма, представляющей собой плоский слой, из-за его охлаждения на кровле возникает неустойчивая стратификация. В условиях неустойчивой стратификации вблизи кровли головы плюма образуется валиковый слой. В нижней части головы плюма тепло отводится от ее подошвы. На подошве создаются условия устойчивой стратификации, и течение расплава вдоль всей нижней части головы плюма происходит в режиме ламинарной свободной конвекции.

Для толщины слоя расплава $l_{\mathrm{p}}=19$ км, кинематической вязкости расплава $v=1-10 \mathrm{~m}^{2} / \mathrm{c}, \lambda=3.5$ $\mathrm{BT} / \mathrm{M} \cdot{ }^{\circ} \mathrm{C}, \quad \beta=10^{-5}{ }^{\circ} \mathrm{C}^{-1}, \quad a=10^{-6} \mathrm{M}^{2} / \mathrm{c}, \quad Q=1.3 \cdot 10^{5} \quad \mathrm{BT} / \mathrm{M}$ получаем $\mathrm{Ra}_{Q}=2.6 \cdot 10^{18}-2.6 \cdot 10^{19}$. Тогда из соотношений (18) и (19) следует: $\Delta T_{\max }=0.10-0.22^{\circ} \mathrm{C}$, $u_{\max }=1.1 \cdot 10^{-4}-5.1 \cdot 10^{-5}$ м/с. Как указано выше, средняя скорость течения расплава $\bar{u}=0.42 u_{\max }$, то есть $\bar{u}=2.1 \cdot 10^{-5}-4.6 \cdot 10^{-5}$ м/с. В течение времени образования батолита расплав циркулирует в голове плюма с периодом $t_{1}$. Длительность одного цикла движения расплава в голове плюма $t_{1}$ можно оценить из соотношения $t_{1}=d_{r^{\prime}} / \bar{u}$. Для $d_{r^{\prime}}=700$ км и полученных выше значений $\bar{u}$ получаем $t_{1}=$ $=(1.5-3.3) \cdot 10^{10} \mathrm{c}(486-1050$ лет $)$.

После осаждения тугоплавких фаз в расплаве головы плюма содержится Ab - $29.11 \%$ и An $32.38 \%$ (см. табл. 2, столбец 4) и, соответственно, $\mathrm{Ab}_{1}-47.3 \%$ и $\mathrm{An}_{1}-52.7 \%$. Принимаем, что кровля 
головы плюма расположена на глубине 5.1 км. В этом случае, согласно диаграмме плавления плагиоклаза, на кровле головы плюма при давлении $P_{\kappa}=1.7$ кбар доля закристаллизовавшегося плагиоклаза $\mathrm{Pl}_{1}$ составит величину 0.51 , а доля расплава 0.49. При давлении на подошве головы плюма $P_{\text {п }}=6.3$ кбар доля закристаллизовавшегося плагиоклаза $\mathrm{Pl}_{1}$ будет 0.65 , а доля расплава 0.35 (см. рис. 4). Таким образом, при увеличении глубины (давления) доля закристаллизовавшегося плагиоклаза $\mathrm{Pl}_{1}$ возрастает.

При осаждении кристаллов плагиоклаза будет увеличиваться содержание плагиоклаза на нижележащих уровнях головы плюма по сравнению с равновесным для данного давления. Для достижения химического равновесия расплава и закристаллизовавшегося плагиоклаза эти излишки должны быть расплавлены при наличии тепловой энергии. В рассматриваемом случае происходит отвод тепла от подошвы головы плюма, поэтому по мере увеличения давления, т.е. по мере приближения к подошве плюма, и на подошве плюма будет происходить обогащение расплава закристаллизовавшимся плагиоклазом. Количество закристаллизовавшегося плагиоклаза в объеме расплава головы плюма будем определять при следующих условиях в окрестности подошвы головы плюма: $P_{n}=6.3$ кбар и $T_{\mathrm{p}}=1410{ }^{\circ} \mathrm{C}$. Принимаем давление $P_{n}=6.3$ кбар как среднее значение между давлением на подошве слоя расплава после осаждения тугоплавких минералов и давлением на подошве слоя расплава после осаждения плагиоклаза. Будем исходить из того, что за время существования плюма, ответственного за образование батолита $t_{0}$ (при числе циклов $t_{0} / t_{1}=10^{4-105}$, где $t_{1}$ - период циркуляции расплава, оцененный выше), произойдет осаждение закристаллизовавшегося плагиоклаза на подошве плюма.

Как указано выше, при $P_{\Pi}=6.3$ кбар доля закри-

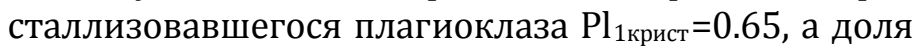
расплава - 0.35. Состав закристаллизовавшегося плагиоклаза $\mathrm{Pl}_{1 \text { крист }}$ отвечает N 65 (An 1крист $=65 \%$ ), состав расплава отвечает N $30\left(\mathrm{An}_{1 \mathrm{p}}-30 \%\right)$ (см. рис. 4). Состав закристаллизовавшегося $\mathrm{Pl}_{1 \text { крист, отве- }}$ чающего N 65: $\mathrm{Ab}_{\text {крист }}=\mathrm{Ab}_{1 \text { крист }}(\mathrm{Ab}+\mathrm{An}) \mathrm{Pl}_{1 \text { крист }}=35 \% \times$ $\times 0.615 \times 0.65=14 \%, \quad \mathrm{An}_{\text {крист }}=\mathrm{An}_{1 \text { крист }}(\mathrm{Ab}+\mathrm{An}) \mathrm{Pl}_{1 \text { крист }}=$ $65 \% \times 0.615 \times 0.65=26 \%$. Используя схему расчетов предыдущего этапа и учитывая процентный состав

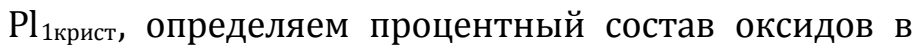
закристаллизовавшемся плагиоклазе (табл. 8, 9).

Вместе с осажденным плагиоклазом $\mathrm{Pl}_{1 \text { крист }}\left(\mathrm{Ab}_{\text {крист }}+\mathrm{An}_{\text {крист }}\right)=0.65 \times 61.5 \%=40 \%$ остается расплав в межкристаллических пространствах: $0.26 \times 40 \%=10.4 \%$. В пересчете на нормативный состав расплав представлен смесью следующих компонентов: Qtz=18.72 \%, Or - 16.78 \%, Ab= $=\left[A b_{1 p}(A b+A n)\left(1-P_{1 \text { крист }}\right)\right]=15.07 \%, A n=\left[\mathrm{An}_{1 \mathrm{p}}(\mathrm{Ab}+\right.$
Т а б л и ц а 8. Содержание оксидов в закристаллизовавшемся альбите (Аb крист)

$\mathrm{T}$ a b l e 8 . The oxide content in crystallized albite

(Ab cryst $_{\text {) }}$

\begin{tabular}{llll}
\hline Оксид & $M_{\text {ох }}$ & $M_{\text {ox }} / M_{\mathrm{Ab}}$ & $\left(M_{\text {ox }} / M_{\mathrm{Ab}}\right) \times 14 \%$ \\
\hline $\mathrm{Na}_{2} \mathrm{O}$ & 61.98 & 0.12 & 1.65 \\
$\mathrm{Al}_{2} \mathrm{O}_{3}$ & 101.96 & 0.19 & 2.72 \\
$6 \mathrm{SiO}_{2}$ & 360.51 & 0.69 & 9.62 \\
\hline
\end{tabular}

Т а б л и ц а 9. Содержание оксидов в закристаллизовавшемся анортите ( $\left.\mathbf{A n}_{\text {крист }}\right)$

$\mathrm{T}$ a b l e 9. The oxide content in crystallized anorthite (An cryst $)$

\begin{tabular}{llll}
\hline Оксид & $M_{\text {ox }}$ & $M_{\text {ox }} / M_{\text {An }}$ & $\left(M_{\text {ox }} / M_{\text {An }}\right) \times 26 \%$ \\
\hline $\mathrm{CaO}$ & 56.08 & 0.20 & 5.25 \\
$\mathrm{Al}_{2} \mathrm{O}_{3}$ & 101.96 & 0.37 & 9.52 \\
$2 \mathrm{SiO}_{2}$ & 120.17 & 0.43 & 11.23 \\
\hline
\end{tabular}

$\left.+\mathrm{An})\left(1-\mathrm{Pl}_{1 \text { крист }}\right)\right]=6.46 \%$ Расплав, который остается вместе с осажденным плагиоклазом, содержит: $\mathrm{Qtz}=0.104 \times 18.72=1.95 \%, \quad$ Or $=0.104 \times 16.78=1.75 \%$, $\mathrm{Ab}=0.104 \times 15.07=1.57 \%, \mathrm{An}=0.104 \times 6.46=0.67 \%$.

Определим процентное содержание оксидов для расплава, оставшегося в межкристаллических пространствах осажденного плагиоклаза (табл. 10-12).

Суммарное содержание каждого оксида для осажденных минералов и расплава в межкристаллических пространствах таково: $\mathrm{SiO}_{2}-23.35 \%, \mathrm{Al}_{2} \mathrm{O}_{3}-$ $13.07 \%, \mathrm{Na}_{2} \mathrm{O}-1.84 \%, \mathrm{CaO}-5.39 \%, \mathrm{~K}_{2} \mathrm{O}-0.3 \%$.

Доля осажденных минералов и расплава в межкристаллическом пространстве составляет 0.44, и толщина слоя расплава, оставшегося после осаждения твердых взвесей плагиоклаза (рис. 6), будет $l_{\mathrm{p}}{ }^{\prime}=(1-0.44) l_{\mathrm{p}}=0.56 l_{\mathrm{p}}$.

Для полученной выше толщины слоя расплава, оставшегося после осаждения тугоплавких минералов, $l_{\mathrm{p}}=19.3-21.9$ км, $l_{\mathrm{p}}{ }^{\prime}=10.8-12.3$ км. После вычитания из столбца 4 табл. 2 процентного содержания соответствующего оксида для осажденных твердых взвесей плагиоклаза получим состав расплава, нормированный на толщину $l_{\mathrm{p}}$ (см. табл. 2 , столбец 5, верхний ярус). Определим процентное содержание оксидов в расплаве головы плюма толщиной $l_{\mathrm{p}}{ }^{\prime}$, получившемся после осаждения плагиоклаза. Суммировав столбец 5 табл. 2 ( $\left.\sum=55.11 \%\right)$ и умножив столбец 5 на величину 100/55.11, получим процентное содержание оксидов в слое остаточного расплава толщиной $l_{\mathrm{p}}{ }^{\prime}$, представленное в столбце 6 табл. 2. 
Т а б л и ц а 10. Содержание оксидов в ортоклазе (Or), оставшемся в осажденном слое плагиоклаза

$\mathrm{T}$ a b l e 10. The oxide content in orthoclase (Or) remaining in the settled plagioclase

\begin{tabular}{llll}
\hline Оксид & $M_{\text {ox }}$ & $M_{\text {ox }} / M_{\text {or }}$ & $\left(M_{\text {ox }} / M_{\text {or }}\right) \times 1.75 \%$ \\
\hline $\mathrm{K}_{2} \mathrm{O}$ & 94.20 & 0.17 & 0.3 \\
$\mathrm{Al}_{2} \mathrm{O}_{3}$ & 101.96 & 0.18 & 0.32 \\
$6 \mathrm{SiO}_{2}$ & 360.51 & 0.65 & 1.13 \\
\hline
\end{tabular}

Т а б л и ц а 11. Содержание оксидов в альбите (Ab), оставшемся в осажденном слое плагиоклаза

$\mathrm{T}$ a b l e 11. The oxide content in albite (Ab) remaining in the settled plagioclase

\begin{tabular}{llll}
\hline Оксид & $M_{\text {ох }}$ & $M_{\text {ox }} / M_{\mathrm{Ab}}$ & $\left(M_{\mathrm{ox}} / M_{\mathrm{Ab}}\right) \times 1.57 \%$ \\
\hline $\mathrm{Na}_{2} \mathrm{O}$ & 61.98 & 0.12 & 0.19 \\
$\mathrm{Al}_{2} \mathrm{O}_{3}$ & 101.96 & 0.19 & 0.30 \\
$6 \mathrm{SiO}_{2}$ & 360.51 & 0.69 & 1.08 \\
\hline
\end{tabular}

Т а б л и ц а 12. Содержание оксидов в анортите (An), оставшемся в осажденном слое плагиоклаза

T a b l e 12. The oxide content in anorthite (An) remaining in the settled plagioclase

\begin{tabular}{llll}
\hline Оксид & $M_{\text {ох }}$ & $M_{\text {ox }} / M_{\text {An }}$ & $\left(M_{\text {ox }} / M_{\text {An }}\right) \times 0.67 \%$ \\
\hline $\mathrm{CaO}$ & 56.08 & 0.20 & 0.14 \\
$\mathrm{Al}_{2} \mathrm{O}_{3}$ & 101.96 & 0.37 & 0.25 \\
$2 \mathrm{SiO}_{2}$ & 120.17 & 0.43 & 0.29 \\
\hline
\end{tabular}

Как следует из столбца 6, содержание $\mathrm{SiO}_{2}$ составляет $76.1 \%$, содержание $\mathrm{SiO}_{2}$ в нормальных гранитах - 70-73 \% [Saranchina, Shinkarev, 1967]. Нормативный состав для расплава представлен в столбце 6 в нижнем ярусе табл. 2. Нормативное содержание $\mathrm{Ab}-24.54 \%$, An - $10.67 \%$, тогда относительное содержание $\mathrm{Ab}_{1}-70 \%, \mathrm{An}_{1}-30 \%$ (см. рис. 4). Согласно диаграмме плавления плагиоклазов (см. рис. 4), такое содержание $\mathrm{Ab}_{1}$ и $\mathrm{An}_{1}$ находится в области ликвидуса системы $\mathrm{Ab}_{1}-\mathrm{An}_{1}$.

Расчеты нормативного состава для нормальных гранитов, исходя из данных [Saranchina, Shinkarev, 1967], дают: Qtz=28-35 \%, Or=27-36\%, Ab=23-26 \%, $\mathrm{An}=1-6 \%$, что удовлетворительно согласуется с данными наших расчетов для компонентов расплава (см. табл. 2, столбцы 6, 8). Таким образом, на основе предложенной модели плюма с грибообразной головой в результате расчетов удалось получить нормативный состав, близкий к составу нормальных гранитов (в отношении Qtz, Or, Ab и An).

\section{8. РАСЧЕТЫ СОСТАВА СЛОЯ РАСПЛАВА И ОСАЖДЕННОГО СЛОЯ ПРИ $T_{\mathrm{P}}=1380{ }^{\circ} \mathrm{C}$}

Рассмотрим случай, когда температура плавления $\mathrm{y}$ кровли грибообразной головы плюма $T_{\mathrm{p}}=1380{ }^{\circ} \mathrm{C}$. Согласно диаграмме плавления плагиоклазов, глубина проплавления коры (глубина залегания подошвы головы плюма) будет $l_{\text {кор }}=28$ км ( $P=9.3$ кбар). Для толщины массива над кровлей плюма $\delta=5$ км толщина слоя расплава грибообразной головы плюма будет $l=l_{\text {кор }}-\delta=23$ км. При $T_{\mathrm{p}}=1380{ }^{\circ} \mathrm{C}$ процентное содержание оксидов в голове плюма после осаждения тугоплавких минералов представлено в табл. 2, столбец 3.

В предыдущем разделе было получено, что процентное содержание осажденной твердой фазы и расплава в межкристаллических пространствах $33.61 \%$, поэтому толщина слоя расплава после осаждения частиц тугоплавких минералов будет $l_{\mathrm{p}}=l(1-0.336)=15.3$ км. Давление на подошве слоя расплава с учетом толщины корового слоя над головой плюма $\delta=5$ км составляет 6.5 кбар. После осаждения плагиоклазовых частиц из расплава, как будет показано ниже, толщина слоя расплава будет $l_{\mathrm{p}}{ }^{\prime}=7.3$ км. Тогда литостатическое давление на подошве слоя расплава, находящейся на глубине $l_{\mathrm{p}}{ }^{\prime}+\delta=12.3$ км, равно 4.1 кбар. Анализ процессов массообмена в голове плюма будем проводить при средней величине $P=5$ кбар. Для $P=5$ кбар на рис. 4 показаны участки кривых ликвидуса $(4 \Omega)$ и солидуса $(4 c)$.

Как следует из рис. 4 , для $P=5$ кбар и $T_{\mathrm{p}}=1380{ }^{\circ} \mathrm{C}$ доля закристаллизовавшегося плагиоклаза $\mathrm{Pl}_{1 \text { крист }}=$ $=0.76$, доля расплава $\mathrm{Pl}_{1 \mathrm{p}}=0.24$. Состав закристаллизовавшегося $\mathrm{Pl}: \quad \mathrm{Ab}_{1 \text { крист }}=38.5 \%, \quad \mathrm{An}_{1 \text { крист }}=61.5 \%$; состав расплава: $\mathrm{Ab}_{1 \mathrm{p}}=75.5 \%, \mathrm{An}_{1 \mathrm{p}}=24.5 \%$. Процентный состав закристаллизовавшихся альбита $\left(A b_{\text {крист }}\right)$ и анортита $\left(A n_{\text {крист }}\right): A b_{\text {крист }}=A b_{1 \text { крист }}(A b+$ $+\mathrm{An}) \mathrm{Pl}_{1 \text { крист }}=38.5 \times 0.615 \times 0.764=18.1 \%, \quad \mathrm{An}_{\text {крист }}=$

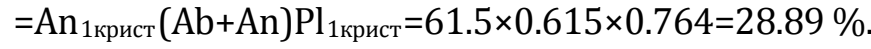

Состав закристаллизовавшегося плагиоклаза и расплава в межкристаллических пространствах в пересчете на оксиды определяем по способу, описанному в разделе 7. Вместе с осажденным плагиоклазом $\mathrm{Pl}_{\text {1крист }}(\mathrm{Ab}+\mathrm{An})=0.764 \times 61.5 \%=47 \%$ в межкристаллических пространствах остается расплав $0.26 \times 47 \%=12.21 \%$. Суммарное значение процентного содержания для каждого оксида для осажденных плагиоклазов и для расплава в межкристаллическом пространстве: $\mathrm{SiO}_{2}=29.6 \%, \mathrm{Al}_{2} \mathrm{O}_{3}=13.88 \%$, $\mathrm{Na}_{2} \mathrm{O}=2.3 \%, \mathrm{CaO}=5.93 \%, \mathrm{~K}_{2} \mathrm{O}=0.35 \%$. Доля осажден- 


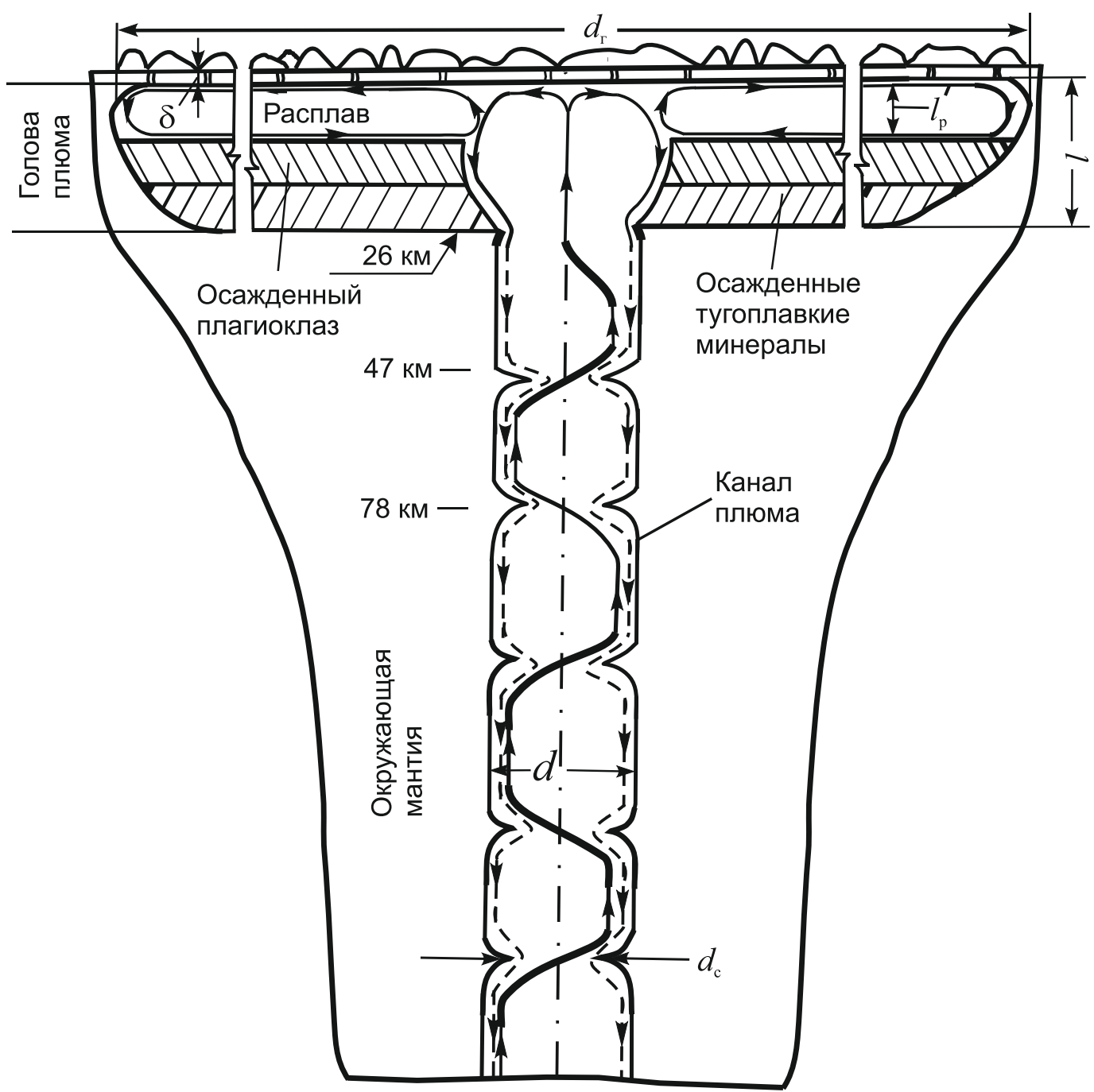

Рис. 6. Схема плюма с грибообразной головой. Диаметр канала плюма $d=29$ км (случай Хэнтэйского плюма). Голова плюма состоит из трех слоев: нижний слой представлен тугоплавкими минералами, осажденными на подошву головы плюма, средний слой представлен осажденным плагиоклазом, верхний слой толщиной $l_{\mathrm{p}}{ }^{\prime}$ представляет собой расплав, остающийся после осаждения частиц плагиоклаза. Показаны свободно-конвективные течения в расплаве канала и грибообразной головы плюма.

Fig. 6. Schematic of the plume with the mushroom-shaped head. The plume conduit diameter is $d=29 \mathrm{~km}$ (the case of Khentei plume). The plume head consists of three layers: lower - settled refractory minerals; middle - settled plagioclase particles; and upper (thickness $l_{\text {melt }}{ }^{\prime}$ ) - the melt remaining after settling of plagioclase. Free-convection flows in the melt of the plume conduit and in the mushroom-shaped plume head are shown.

ных плагиоклазов и расплава в межкристаллическом пространстве составляет 0.52. Тогда толщина слоя остаточного расплава $l_{\mathrm{p}}{ }^{\prime}=l_{\mathrm{p}}(1-0.52)=0.48 l_{\mathrm{p}}$. Для $l_{\mathrm{p}}=15.3 \mathrm{\kappa м}, l_{\mathrm{p}}{ }^{\prime}=7.3 \mathrm{\kappa м}$.

После вычитания из столбца 4 (см. табл. 2) для соответствующего оксида процентного содержания осажденного оксида получим состав остаточного расплава (см. табл. 2, столбец 7). Суммировав столбец 7 в табл. 2 ( $\left.\sum=47 \%\right)$ и умножив его на величину 100/47, получаем процентное содержание оксидов для слоя остаточного расплава толщиной $l_{\mathrm{p}}{ }^{\prime}$, представленное в столбце 8 табл. 2. Содержание $\mathrm{SiO}_{2}$ в остаточном расплаве составляет 76 \%. Нор- мативный состав представлен в столбце 8 (нижний ярус). Как следует из столбца 8, содержание $\mathrm{Ab}-$ $20.56 \%$, An - $8.48 \%$.

Как показывают наши оценки, с уменьшением температуры плавления на кровле плюма происходит уменьшение толщины расплавленного корового слоя $l$ и уменьшение толщины слоя остаточного расплава головы плюма $l_{\mathrm{p}}$ (рис. 6), состав которого близок к гранитному. Так, при изменении температуры плавления от 1410 до $1380{ }^{\circ} \mathrm{C}$ толщина расплавленного корового слоя уменьшается от 31 до 23 км. Толщина слоя гранитного расплава уменьшается от 10.8 до 7.3 км. Доля гранитного расплава 
от всего расплавленного корового слоя соответственно уменьшается от 40 до $32 \%$.

Анализ процессов тепло- и массообмена в голове плюма позволяет представить структуру головы плюма в период, когда расплав имеет состав, близкий к гранитному, т.е. в период, когда голова плюма уже сформировалась, достигла наибольшего диаметра и в ней по достижении этого диаметра постепенно образовался гранитный расплав. Для Хэнтэйского плюма структура представлена на рис. 5, 6.

Как показано в предыдущем разделе, в процессе осаждения твердой фазы (тугоплавких минералов) первоначальная толщина слоя расплава $l$, соизмеримая с величиной диаметра канала, уменьшается до толщины расплава $l_{\mathrm{p}}$ (см. рис. 5). Для $l=29$ км $T_{\text {пл }}=1410{ }^{\circ} \mathrm{C}$ имеем $l_{\mathrm{p}}=19.3$ км. Далее происходит осаждение частиц плагиоклаза в получившемся расплаве. После осаждения частиц плагиоклаза толщина слоя расплава $l_{\mathrm{p}}{ }^{\prime}$ (рис. 6) будет: $l_{\mathrm{p}}{ }^{\prime}=10.8$ км для $T_{\mathrm{p}}=1410^{\circ} \mathrm{C}$.

Скорость осаждения твердых взвесей - кристаллитов тугоплавких минералов - в расплаве головы плюма можно оценить с использованием формулы Стокса для скорости движения шара $U_{\text {ш }}$ радиусом $r$ в вязкой жидкости: $U_{ш}=2 r^{2} g \Delta \rho / 9 \eta$ ( - динамическая вязкость расплава) (например [Winter, 2014]). В первом приближении, исходя из экспериментальных значений динамической вязкости в системе альбит-анортит (для $T=1400^{\circ} \mathrm{C}$ ) [Cranmer, Uhlmann, 1981], принимаем $\eta=10^{2}-10^{3}$ Па.с. С учетом плотностей пироксенов и плагиоклаза разность плотностей частиц осаждающихся минералов и рас-

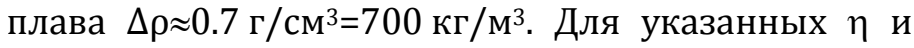
$\Delta \rho$ скорость осаждения шарика радиусом $r=$ $=(0.25-1) \cdot 10^{-3}$ м в объеме расплава со средней плотностью $\rho=2670$ кг $/ \mathrm{M}^{3}$ будет $U_{ш}=9.5 \cdot 10^{-8}-1.5 \cdot 10^{-5} \bar{u}$, или 3-481 м/год. Горизонтальные свободно-конвективные течения в расплаве головы плюма у кровли и подошвы слоя расплава направлены противоположно друг другу (см. рис. 4). Исходя из этого, время осаждения частиц тугоплавких минера-

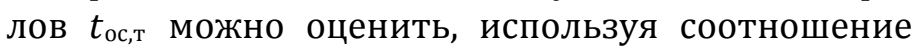

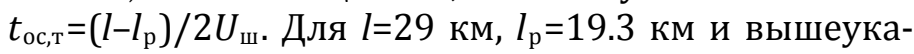
занных значений $U_{ш} t_{\text {ос,т }}=10-1614$ лет. Следует отметить, что присутствие твердой фазы во взвешенном состоянии в расплаве может существенно повысить его динамическую вязкость (например [Marsh, 1981]). В нашем случае в расплаве могут находиться частицы плагиоклаза и кварца (см. ниже). Для доли твердой фазы в расплаве, равной $30 \%$, вязкость может вырасти в 2-3 раза, для равной $50 \%$ - примерно в 6 раз [Persikov, 1984]. Это вызовет соответствующее уменьшение скорости и увеличение времени осаждения. Однако в любом случае время $t_{\text {ос,т }}$ оказывается много меньше времени существования плюма, ответственного за об- разование крупного интрузивного тела (батолита) $t_{\text {инт, }}$ которое составляет 20-30 млн лет [Kirdyashkin A.G., Kirdyashkin A.A., 2016].

Для расплава головы плюма нормативное содержание $A b=21.15 \%, A n=23.51 \%$ (см. табл. 2, столбец 2). Исходя из динамической вязкости в системе альбит-анортит, принимаем (для $\mathrm{Ab}_{50} \mathrm{An}_{50}, \mathrm{~T}=1400{ }^{\circ} \mathrm{C}$ ) $\eta=10^{2}$ Па.с [Cranmer, Uhlmann, 1981]. Скорость осаждения шарика радиусом $r=(0.5-2) \cdot 10^{-3}$ м в объеме расплава со средней плотностью $\rho=2670$ кг $/ \mathrm{m}^{3}$, согласно формуле Стокса, будет $U_{ш}=3.3 \cdot 10^{-7}$ $-5.2 \cdot 10^{-6} \mathrm{M} / \mathrm{c}$, или 10-165 м/год для $\Delta \rho=0.06$ г $/ \mathrm{cm}^{3}=$ $=60$ кг $/ \mathrm{M}^{3}$. Горизонтальные свободно-конвективные течения в расплаве у кровли и подошвы головы плюма, в котором осаждаются частицы плагиоклаза, направлены противоположно друг другу (см. рис. 4). Исходя из этого, время осаждения $t_{\mathrm{oc}, \mathrm{Pl}}=$ $=\left(l_{\mathrm{p}}-l_{\mathrm{p}}{ }^{\prime}\right) / 2 U_{ш}$. Для $l_{\mathrm{p}}=19.3$ км и $l_{\mathrm{p}}{ }^{\prime}=10.8 \mathrm{\kappa м}, t_{\mathrm{oc}, \mathrm{Pl}}=$ =26-412 лет. Присутствие кристаллов кварца в расплаве и наличие ортоклазового компонента (Or= $=12.41 \%$ ) могут увеличить вязкость расплава. Однако и при ее увеличении на 1-2 порядка $t_{\text {oc,pl }}<<t_{\text {инт }}$. Таким образом, за время существования плюма произойдет осаждение твердых взвесей плагиоклаза.

Специфика взаимоотношения расплава в канале плюма с расплавом в голове плюма состоит в том, что плотность расплава в канале больше плотности расплава в голове и в период ее роста, и особенно в период, когда состав расплава в голове плюма близок к гранитному. Передача тепла от канала к голове плюма происходит как теплообмен между восходящим свободно-конвективным потоком в голове плюма и нисходящим свободно-конвективным потоком в канале плюма [Kirdyashkin et al., 2017].

Под действием сверхлитостатического давления в голове плюма через ее кровлю выдавливается расплав, массовый расход которого $\Delta G=N C / \beta$. Для Хэнтэйского плюма $\Delta G=634$ кг/с (см. табл. 1). Такой расход расплава из канала плюма поступает в грибообразную голову в течение всего времени существования плюма, т.е. во время формирования интрузий, представляющих собой поверхностные проявления Хэнтэйского плюма. Площадь проявления на поверхности Хэнтэйского батолита, имеющего размеры $d_{\mathrm{r}}{ }^{\prime}=700$ км и $d_{\mathrm{r}}{ }^{\prime \prime}=224$ км [Kuzmin et al., 2010], составляет $1.57 \cdot 10^{5} \mathrm{kM}^{2}$. Толщина слоя гранитного расплава (рис. 6) $l_{\mathrm{p}}=10.8$ км. Предполагая, что площадь грибообразной головы плюма соответствует площади, на которой образуется батолит, определим объем расплава в голове плюма: $V_{\mathrm{p}}=d_{\mathrm{r}}{ }^{\prime} d_{\mathrm{r}}{ }^{\prime \prime} l_{\mathrm{p}}{ }^{\prime}$, т.е. $V_{\mathrm{p}}=1.62 \cdot 10^{6} \mathrm{\kappa m}^{3}$. Объем магм, выдавленных в коровый слой над головой плюма, составляет $V=2 \cdot 10^{5}$ км$^{3}$ [Kirdyashkin A.A., Kirdyashkin A.G., 2016]. Таким образом, доля расплава, поступившего в голову плюма из его канала за время образования батолита, $V / V_{\mathrm{p}}=0.123$. 
Таким образом, результатами исследований, представленных в разделах 6-8, являются следующие. На основе геологических данных определена тепловая мощность плюмов с грибообразной головой, ответственных за образование крупных интрузивных тел (батолитов). Для этого исследованы гидродинамика и теплообмен в канале и грибообразной голове плюма. Под действием сверхлитостатического давления на кровле грибообразной головы плюма происходит выдавливание расплава головы плюма в коровый массив над ней и затвердевание расплава в виде локальных проявлений основного интрузивного тела - корневого батолита.

На втором этапе для состава корового слоя по А. Ронову и А. Ярошевскому и при температуре его плавления $T_{\mathrm{p}}=1410{ }^{\circ} \mathrm{C}$ и $1380{ }^{\circ} \mathrm{C}$ рассмотрен тепло- и массообмен в расплаве головы плюма. Расчеты показали, что вследствие кристаллизационной дифференциации расплава головы плюма образуется остаточный расплав, по составу близкий к гранитному. Поскольку температура плавления «сухого» гранита 1215-1260 ${ }^{\circ} \mathrm{C}$ [Larsen, 1929], перегретый гранитный расплав выдавливается в местах разломов в твердый массив над кровлей головы плюма. В процессе внедрения гранитный расплав, подплавляя твердый массив, захватывает частицы различных нерасплавленных минералов. Таким образм, образование остаточного расплава, его внедрение в коровый слой и формирование гранитов являются следствием деятельности мантийных термохимических плюмов с грибообразной головой.

\section{9. ЗАКЛЮЧЕНИЕ}

Грибообразная голова плюма возникает после прорыва плюма на поверхность при значениях относительной тепловой мощности $1.9<\mathrm{Ka}<10$. Тепловая мощность, отводимая от кровли плюма в атмосферу через массив коры над кровлей плюма, меньше тепловой мощности, передаваемой к кровле плюма, и поэтому происходит плавление вдоль подошвы массива и образуется грибообразная голова плюма, т.е. формируется корневой батолит. Под действием сверхлитостатического давления в расплаве у кровли плюма может происходить выдавливание магмы в зонах разломов корового массива над головой плюма. Определены основные параметры (массовый расход расплава, тепловая мощность, диаметр канала и головы) некоторых плюмов Северной Азии, имеющих грибообразную голову.

Гидродинамика и теплообмен в грибообразной голове плюма рассмотрены на основе модели плоского горизонтального слоя жидкости. Согласно полученным оценкам, сверхадиабатические перепады температуры в грибообразной голове плюма $\sim 0.2{ }^{\circ} \mathrm{C}$, поэтому на процессы кристаллизационной дифференциации в большей степени должно влиять изменение давления по высоте слоя, вследствие изменения диаграммы плавкости плагиоклазов с давлением. Изменение состава расплава в голове плюма оценено для двух последовательных этапов: 1) после осаждения кристаллитов тугоплавких минералов на подошву головы плюма, 2) после осаждения плагиоклаза в расплаве, образовавшемся после первого этапа и содержащем 61.5 \% плагиоклазового компонента.

Результаты расчетов состава расплава головы плюма представлены для температуры расплава $T_{\mathrm{p}}=1410$ и $1380{ }^{\circ} \mathrm{C}$. В результате расчетов на основе предложенной модели тепловой и гидродинамической структуры плюма с грибообразной головой для расплава головы плюма был получен нормативный состав, близкий к составу нормальных гранитов (в отношении Qtz, Or, Ab и An). При уменьшении температуры расплава от 1410 до $1380{ }^{\circ} \mathrm{C}$ толщина расплавленного слоя коры $l$ уменьшается от 31 до 23 км. Толщина слоя расплава в грибообразной голове плюма, состав которого близок к гранитному $\left(l_{\mathrm{p}}{ }^{\prime}\right)$, уменьшается от 10.8 до 7.3 км. Доля гранитного расплава от всего расплавленного корового слоя соответственно уменьшается от 40 до $32 \%$.

Основная задача заключалась в определении закономерностей тепло- и массопереноса в расплаве, образующемся вследствие плавления корового слоя, средний химический состав которого взят по А. Ронову и А. Ярошевскому. При плавлении земной коры источником тепла служит мантийный термохимический плюм. Анализ процессов кристаллизационной дифференциации расплава в голове плюма указал на образование остаточного расплава, состав которого в отношении таких компонентов, как Qtz, Or, Ab и An, близок к составу нормальных гранитов. Перегретый остаточный расплав, температура которого $T_{\text {p }}$ выше температуры плавления сухого гранита, внедряясь в массив над головой плюма, будет расплавлять вмещающие породы. При взаимодействии остаточного расплава с ними происходят реакции и его обогащение различными компонентами, включая и те, которые понижают температуру начала кристаллизации. На последних стадиях эволюции остаточного расплава, обогащенного вышеуказанными примесями, происходит его затвердевание и образование гранита. На заключительных стадиях процесс образования гранитов может протекать в соответствии с параметрами петрологических моделей, имеющихся в литературе, в том числе упомянутых во введении. Процессы взаимодействия перегретого остаточного расплава с вмещающими породами массива над головой плюма требуют специального рассмотрения, выходящего за рамки настоящей статьи. 


\section{0. БЛАГОДАРНОСТИ}

Работа выполнена в рамках государственного задания, проект № 0330-2016-0016 «Моделирование тепловой и гидродинамической структуры плюмов для определения условий формирования магматических расплавов и их влияния на вещественный состав и структуру литосферы Северной Евразии».

\section{1. ЛИТЕРАTУРA / REFERENCES}

Bowen N.L., 1913. The melting phenomena of the plagioclase feldspars. American Journal of Science 35 (210), 577-599. https://doi.org/10.2475/ajs.s4-35.210.577.

Brandon A.D., Walker R.J., 2005. The debate over core-mantle interaction. Earth and Planetary Science Letters 232 (3-4), 211-225. https://doi.org/10.1016/j.epsl.2005.01.034.

Brown M., 2013. Granite: from genesis to emplacement. Geological Society of America Bulletin 125 (7-8), 1079-1113. https://doi.org/10.1130/B30877.1.

Brückner R., 2003. Silicon dioxide. In: G.L. Trigg (Ed.), Encyclopedia of Applied Physics. Wiley, New York, p. 101-131. https://doi.org/10.1002/3527600434.eap432.

Cranmer D., Uhlmann D.R., 1981. Viscosities in the system albite-anorthite. Journal of Geophysical Research: Solid Earth 86 (B9), 7951-7956. https://doi.org/10.1029/JB086iB09p07951.

Cross W., Iddings J.P., Pirsson L.V., Washington H.S., 1902. A quantitative chemicomineralogical classification and nomenclature of igneous rocks. The Journal of Geology 10 (6), 555-690. https://doi.org/10.1086/621030.

Dobretsov N.L., Kirdyashkin A.A., Kirdyashkin A.G., Vernikovsky V.A., Gladkov I.N., 2008. Modelling of thermochemical plumes and implications for the origin of the Siberian traps. Lithos 100 (1-4), 66-92. https://doi.org/10.1016/ j.lithos.2007.06.025.

Dobretsov N.L., Kirdyashkin A.G., 2000. Sources of mantle plumes. Doklady Earth Sciences 373 (5), 879-881.

Dobretsov N.L., Kirdyashkin A.G., Kirdyashkin A.A., 2001. Deep Geodynamics. Siberian Branch of RAS Publishing House, Geo Branch, Novosibirsk, 408 p. (in Russian) [Добрецов Н.Л., Кирдяшкин А.Г., Кирдяшкин А.А. Глубинная геодинамика. Новосибирск: Изд-во СО РАН, филиал «ГЕО», 2001. 408 с.].

Dobretsov N.L., Kirdyashkin A.G., Kirdyashkin A.A., 2005. Parameters of hot spots and thermochemical plumes. Geologiya i Geofizika (Russian Geology and Geophysics) 46 (6), 589-602.

Frye K. (Ed.), 1983. The Encyclopedia of Mineralogy. Springer, Berlin, 794 р. [Русский перевод: Минералогическая энциклопедия / Ред. К. Фрей. Л.: Недра, 1985. 512 с.].

Gladkov I.N., Distanov V.E., Kirdyashkin A.A., Kirdyashkin A.G., 2012. Stability of a melt/solid interface with reference to a plume channel. Fluid Dynamics 47 (4), 433-447. https://doi.org/10.1134/S0015462812040023.

Gramenitsky E.N., Kotelnikov A.R., Batanova A.M., Shchekina T.I., Plechov P.Yu., 2000. Experimental and Technological Petrology. Nauchnyi Mir, Moscow, 416 p. (in Russian] [Граменицкий Е.Н., Котельников А.Р., Батанова А.М., Щекина Т.И., Плечов П.Ю. Экспериментальная и техническая петрология. М.: Научный мир, 2000. 416 с.].

Jaupart C., Mareschal J.-C., 2007. Heat flow and thermal structure of the lithosphere. In: G. Schubert (Ed.), Treatise on geophysics. Vol. 6. Crust and lithosphere dynamics. Elsevier, p. 217-251. https://doi.org/10.1016/B978044452748-6.00104-8.

Jaupart C., Mareschal J.-C., 2014. Constraints on crustal heat production from heat flow data. In: H. Holland, K. Turekian (Eds.), Treatise on geochemistry (Second Edition). Vol. 4. The crust. Elsevier, p. 53-73. https://doi.org/10.1016/ B978-0-08-095975-7.00302-8.

Johannes W., 1984. Beginning of melting in the granite system Qz-Or-Ab-An- $\mathrm{H}_{2} \mathrm{O}$. Contributions to Mineralogy and Petrology 86 (3), 264-273. https://doi.org/10.1007/BF00373672.

Kirdyashkin A.A., Dobretsov N.L., Kirdyashkin A.G., 2004. Thermochemical plumes. Geologiya i Geofizika (Russian Geology and Geophysics) 45 (9), 1005-1024.

Kirdyashkin A.A., Kirdyashkin A.G., 2016. On thermochemical mantle plumes with an intermediate thermal power that erupt on the Earth's surface. Geotectonics 50 (2), 209-222. https://doi.org/10.1134/S0016852116020059.

Kirdyashkin A.A., Kirdyashkin A.G., Distanov V.E., Gladkov I.N., 2016. Geodynamic regimes of thermochemical mantle plumes. Russian Geology and Geophysics 57 (6), 858-867. https://doi.org/10.1016/j.rgg.2016.05.003.

Kirdyashkin A.A., Kirdyashkin A.G., Gurov V.V., 2017. Parameters of thermochemical plumes responsible for the formation of batholiths: results of experimental simulation. Geotectonics 51 (4), 398-411. https://doi.org/10.1134/ S0016852117040057.

Kirdyashkin A.G., Kirdyashkin A.A., 2016. Parameters of plumes of North Asia. Russian Geology and Geophysics 57 (11), 1535-1550. https://doi.org/10.1016/j.rgg.2016.10.002.

Kuzmin M.I., Yarmolyuk V.V., Kravchinsky V.A., 2010. Phanerozoic hot spot traces and paleogeographic reconstructions of the Siberian continent based on interaction with the African large low shear velocity province. Earth-Science Reviews 102 (1-2), 29-59. https://doi.org/10.1016/j.earscirev.2010.06.004. 
Larsen E.S., 1929. The temperatures of magmas. American Mineralogist 14, 81-94.

Luth W.C., Jahns R.H., Tuttle O.F., 1964. The granite system at pressures of 4 to 10 kilobars. Journal of Geophysical Research 69 (4), 759-773. https://doi.org/10.1029/JZ069i004p00759.

Maaløe S., Wyllie P.J., 1975. Water content of a granite magma deduced from the sequence of crystallization determined experimentally with water-undersaturated conditions. Contributions to Mineralogy and Petrology 52 (3), 175-191. https://doi.org/10.1007/BF00457293.

Marsh B.D., 1981. On the crystallinity, probability of occurrence and rheology of lava and magma. Contributions to Mineralalogy and Petrology 78 (1), 85-98. https://doi.org/10.1007/BF00371146.

Maruyama S., 1994. Plume tectonics. Journal of the Geological Society of Japan 100 (1), 24-49. https://doi.org/ 10.5575/geosoc.100.24.

Nekrasov B.V., 1973. Fundamentals of General Chemistry. Vol. 1. Khimiya Publishing House, Leningrad, 656 p. (in Russian) [Некрасов Б.В. Основы общей химии. Т. 1. Л.: Изд-во «Химия», 1973. 656 с.].

Pabst W., Gregorová E., 2013. Elastic properties of silica polymorphs - a review. Ceramics - Silikáty 57 (3), 167-184.

Persikov E.S., 1984. The Viscosity of Magmatic Melts. Nauka, Moscow, 160 p. (in Russian) [Персиков Э.С. Вязкость магматических расплавов. М.: Наука, 1984. 160 с.].

Saranchina G.M., Shinkarev N.F., 1967. Petrography of Magmatic and Metamorphic Rocks. Nedra, Leningrad, 324 p. (in Russian) [Саранчина Г.М., Шинкарев Н.Ф. Петрография магматических и метаморфических пород. Л.: Недра, 1967. 324 c.].

Sobolev V.S., 1986. Petrology of Traps. Nauka, Novosibirsk, 209 p. (in Russian) [Соболев В.C. Петрология траппов. Новосибирск: Наука. СО, 1986. 209 с.].

Tuttle O.F., Bowen N.L., 1958. Origin of granite in the light of experimental studies in the system $\mathrm{NaAlSi}_{3} \mathrm{O}_{8}-\mathrm{KAlSi}_{3} \mathrm{O}_{8}-$ $\mathrm{SiO}_{2}-\mathrm{H}_{2} \mathrm{O}$. In: Geological Society of America Memoirs, vol. 74, p. 1-146. https://doi.org/10.1130/MEM74-p1.

Vertushkov G.N., Avdonin V.N., 1992. Tables for Mineral Determination Based on Chemical and Physical Properties: A Handbook. Nedra, Moscow, 489 p. (in Russian) [Вертушков Г.Н., Авдонин В.Н. Таблицы для определения минералов по физическим и химическим свойствам: Справочник. М.: Недра, 1992. 489 с.].

Vogt P.R., 1979. Global magmatic episodes: new evidence and implications for the steady-state mid-oceanic ridge. Geology 7 (2), 93-98. https://doi.org/10.1130/0091-7613(1979)7<93:GMENEA>2.0.C0;2.

Voitkevich G.V., Kokin A.V., Miroshnikov A.E., Prokhorov V.G., 1990. Geochemistry Reference Book. Nedra, Moscow, 480 p. (in Russian) [Войткевич Г.В., Кокин А.В., Мирошников А.Е., Прохоров В.Г. Справочник по геохимии. М.: Недра, 1990. 480 с.].

Walzer U., Hendel R., Baumgardner J., 2004. The effects of a variation of the radial viscosity profile on mantle evolution. Tectonophysics 384 (1-4), 55-90. https://doi.org/10.1016/j.tecto.2004.02.012.

Whitney J.A., 1988. The origin of granite: the role and source of water in the evolution of granitic magmas. Geological Society of America Bulletin 100 (12), 1886-1897. http://dx.doi.org/10.1130/0016-7606(1988)100\%3C1886: TOOGTR\%3E2.3.CO;2.

Winter J.D., 2014. Principles of Igneous and Metamorphic Petrology. Harlow, Pearson, 739 p.

Zonenshain L.P., Kuzmin M.I., Bocharova N.Yu., 1991. Hot-field tectonics. Tectonophysics 199 (2-4), 165-192. https:// doi.org/10.1016/0040-1951(91)90171-N.

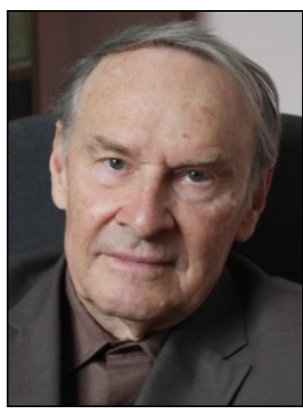

Анатолий Григорьевич Кирдяшкин, докт. техн. наук, в.н.с. Институт геологии и минералогии им. В.С. Соболева СО РАН 630090, Новосибирск, пр. Академика Коптюга, 3, Россия 凶e-mail:agk@igm.nsc.ru

Anatoly G. Kirdyashkin, Doctor of Technical Sciences, Lead Researcher V.S. Sobolev Institute of Geology and Mineralogy, Siberian Branch of RAS 3 Academician Koptyug ave., Novosibirsk 630090, Russia

\e-mail:agk@igm.nsc.ru 
A.G. Kirdyashkin, A.A. Kirdyashkin: Hydrodynamics and heat and mass transfer...

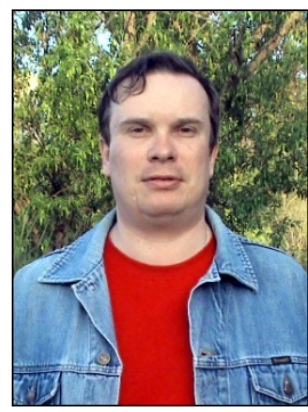

Алексей Анатольевич Кирдяшкин, докт. геол.-мин. наук, профессор РАН, зав. лабораторией Институт геологии и минералогии им. В.С. Соболева СО РАН

630090, Новосибирск, просп. Академика Коптюга, 3, Россия

Новосибирский национальный исследовательский государственный университет

630090, Новосибирск, ул. Пирогова, 2, Россия

e-mail: aak@igm.nsc.ru

Alexei A. Kirdyashkin, Doctor of Geology and Mineralogy, Professor of RAS, Head of Laboratory

V.S. Sobolev Institute of Geology and Mineralogy, Siberian Branch of RAS

3 Academician Koptyug ave., Novosibirsk 630090, Russia

Novosibirsk National Research State University

2 Pirogov street, Novosibirsk 630090, Russia

e-mail: aak@igm.nsc.ru 